\title{
Treatment of Giardiasis
}

\author{
TIMOTHY B. GARDNER AND DAVID R. HILL* \\ Division of Infectious Diseases, University of Connecticut Health Center, Farmington, Connecticut
}

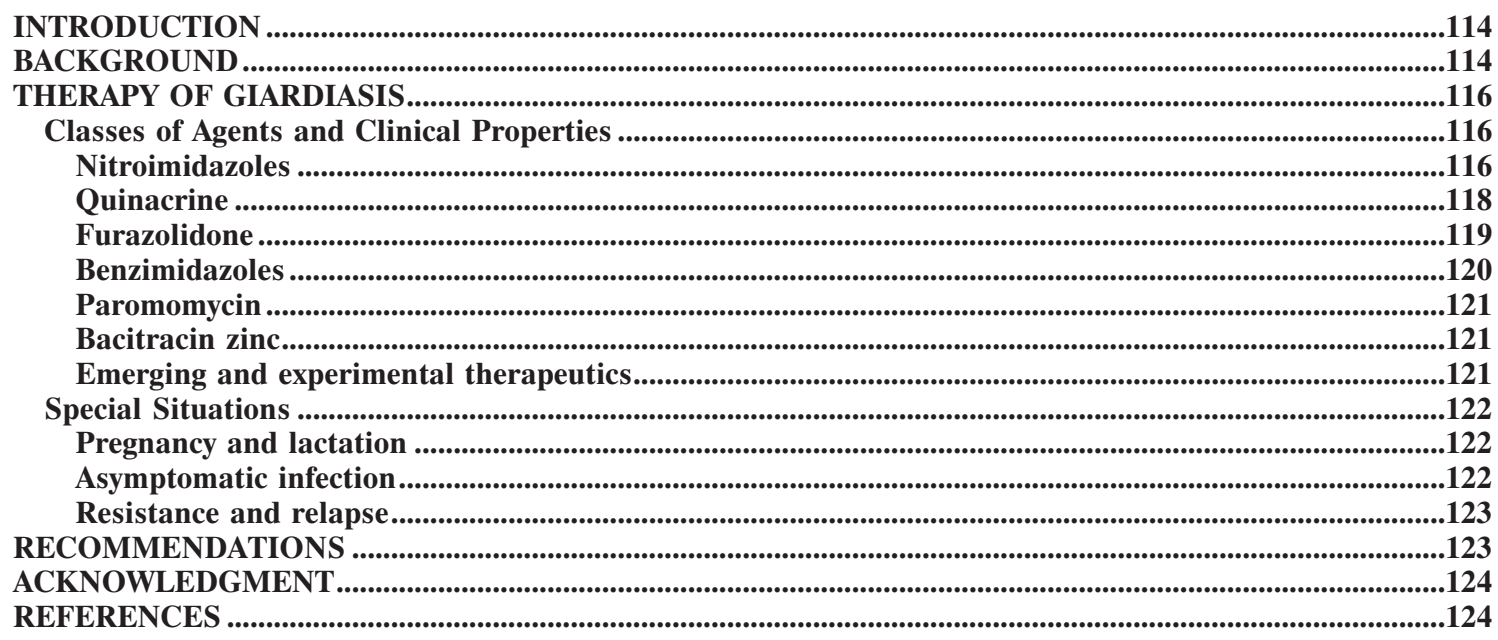

\section{INTRODUCTION}

Giardia lamblia, also called Giardia duodenalis or Giardia intestinalis, is a protozoan parasite of the small intestine that causes extensive morbidity worldwide. It was first described in the late 17th century by the Dutch microscopist Antonie van Leeuwenhoek (62), and research into its epidemiology, pathogenesis, and treatment has intensified since G. lamblia waterborne outbreaks were reported in Europe and the United States during the 1960s and 1970s (53, 81, 123, 128, 174). Giardia infects approximately $2 \%$ of the adults and 6 to $8 \%$ of the children in developed countries worldwide and is currently responsible for the largest number of waterborne outbreaks of diarrhea in the United States $(54,139)$.

Despite the recognition of G. lamblia clinical illness for the last 40 years, the nearly 5,000 people hospitalized with giardiasis annually in the United States (149), and the millions infected worldwide, there have been few reviews of therapy for this infection and no definitive treatment protocols have been published $(58,113,150,165,261)$. In addition, only a handful of agents have been used in therapy, and the agents which are available may have adverse effects or be contraindicated in certain clinical situations. Also, resistance may play a role in some infections. This paper will review the agents currently used for the treatment of giardiasis. The history, mechanism of action, in vitro and clinical studies, and adverse effects are detailed for each drug class. In addition, special clinical situations are discussed and recommendations for therapy are made.

\footnotetext{
* Corresponding author. Mailing address: Division of Infectious Diseases, University of Connecticut Health Center, Farmington, CT 06030-3212. Phone: (860) 679-4700. Fax: (860) 679-4701. E-mail: dhill @exchange.uchc.edu.
}

\section{BACKGROUND}

The life cycle of G. lamblia has two forms: the trophozoite (Fig. 1) and the cyst. The cyst is the infectious form and is ingested in contaminated water or food or directly from fecaloral contact. As few as 10 cysts may establish infection (206). After ingestion, excystation occurs. Excystation is thought to be initiated by contact with acidic gastric contents, followed by a highly coordinated sequence of events leading to the release of one or two trophozoites $(27,109,210)$. A parasite-derived protease may be activated during the excystation process (252). The trophozoite infects the duodenum and upper intestine, which have a favorable alkaline $\mathrm{pH}$, and gives rise to the clinical sequelae. As trophozoites pass through the small intestine to the colon, encystation occurs. Encystation can be initiated in vitro by culture of parasites in a reduced concentration of bile salts and cholesterol followed by culture in an increased concentration of bile at an alkaline $\mathrm{pH}$ (156). Cyst wall proteins are then transcribed, secreted into encystmentspecific vesicles, and transported to the newly forming cell wall over 14 to $16 \mathrm{~h}(75)$.

The wide variety of clinical presentations, from severe disease to an asymptomatic carrier state, makes the definitive determination of pathogenesis difficult. However, several theories have been put forward $(83,115)$. Some of the most likely include the ability of the protozoan to cause direct damage to the intestinal mucosa via adherence with the disk, disaccharidase enzyme reduction following brush border damage, the release from Giardia of cytopathic substances such as thiol proteinases and lectins, and the stimulation of a host immune response with release of cytokines and mucosal inflammation $(41,48,61,78,83,106,110,157,259)$. Additionally, it is likely that there are genetic differences between Giardia isolates which may confer virulence $(115,173,182,190)$. The surface of Giardia may also undergo antigenic variation in the human 


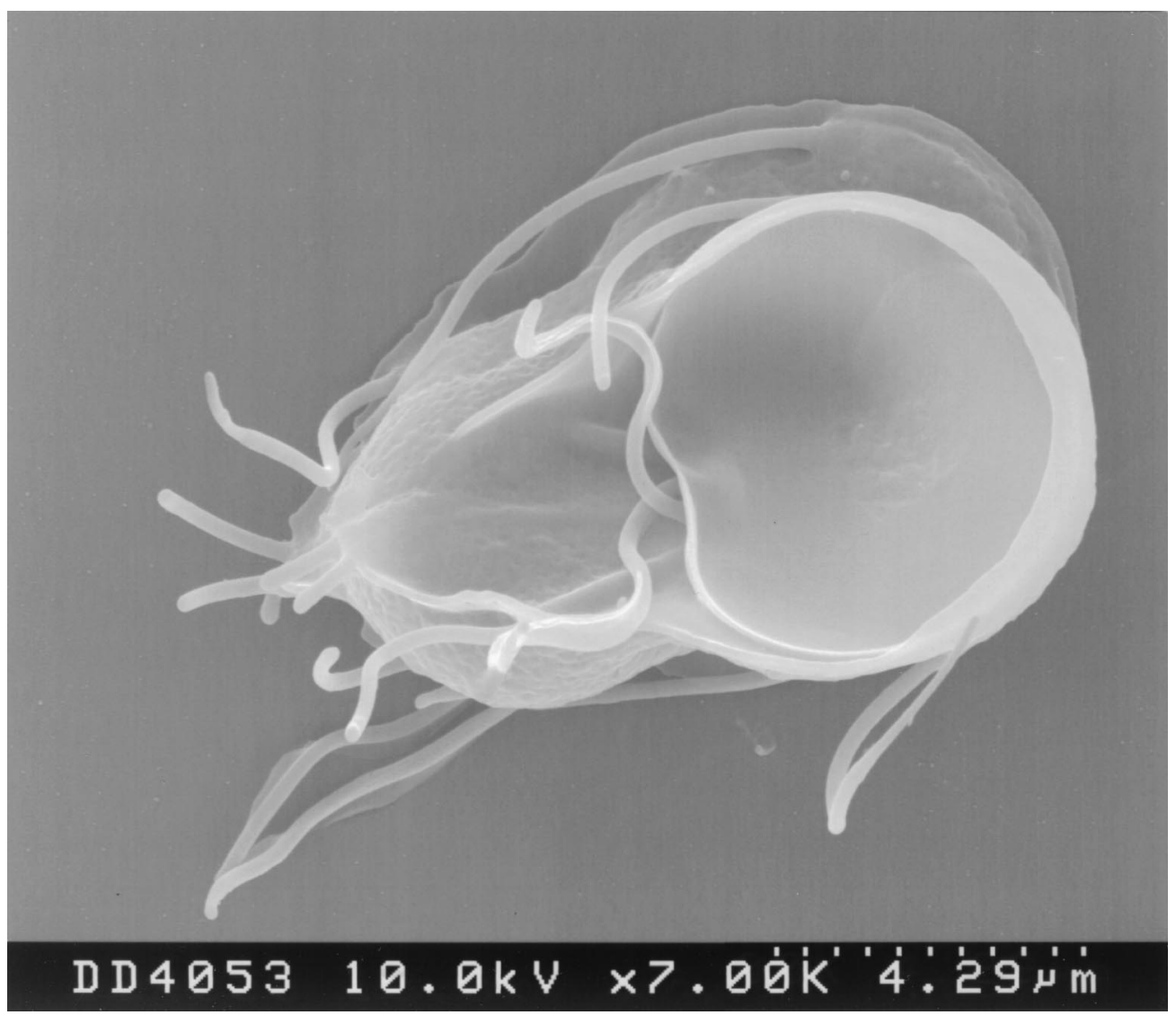

FIG. 1. Ventral surface of a Giardia lamblia trophozoite imaged by scanning electron microscopy. It demonstrates the disk and flagella. A second trophozoite is seen behind it. Magnification, $\times 8,100$. Photo courtesy of David Dorward, Rocky Mountain Laboratory, National Institutes of Health, Hamilton, Mont.

host and thus evade immune detection (181). Given these multiple potential mechanisms, a multifactoral process is likely.

G. lamblia is found primarily in mammals including humans, cats, dogs, beavers, and cattle $(40,74,77,257)$. Transmission of the $G$. lamblia cyst to humans occurs most commonly following ingestion of contaminated water (139). Transmission via surface water is facilitated by the relative resistance of the cyst to chlorination and its ability to survive in cold water for weeks $(59,122)$. Transmission by food $(22,152,187)$, by direct fecaloral contact among children in day care $(28,224,237)$ or in developing-world settings $(96,159)$, and by sexual practices which include oral-anal contact (168) represent other common modes of transmission (113). G. lamblia is also seen as a cause of prolonged diarrhea in travelers $(37,66,125,136,205 ; \mathrm{N}$. Fiumara, Letter, N. Engl. J. Med. 288:1410-1411, 1973).

Worldwide, the majority of patients infected with G. lamblia are asymptomatic. However, typical clinical symptoms of giardiasis usually begin 1 to 3 weeks after ingestion of cysts and are marked by diarrhea, malaise, flatulence, greasy stools, and abdominal cramps $(113,256)$. Other symptoms commonly include bloating, weight loss (174), and anorexia. Vomiting and fever are less common, and blood- or mucus-tinged feces are rare. Illness can last several months if untreated and can be characterized by continued exacerbations of diarrheal symp- toms. With chronic illness, malabsorption of fat, lactose, vitamin $\mathrm{A}$, and vitamin $\mathrm{B}_{12}$ are reported, and failure of children to thrive has been noted $(86,112,149,184,227)$.

Giardiasis should be considered in the differential diagnosis of many diarrheal syndromes. A careful history, which notes any risk factors such as recent travel, wilderness exposure, or situations involving poor fecal-oral hygiene, and a physical examination are essential. Infection with $G$. lamblia can often be distinguished from bacterial and viral infections because of the longer duration of illness, 7 to 10 days by the time of presentation, and the presence of weight loss (113). Parasitic diarrhea with Cryptosporidium or Cyclospora can have similar features in the immunologically normal host and would need to be distinguished by specific diagnostic testing $(50,99)$.

Several methods exist for detection of the parasite. Demonstration of trophozoites or cysts in the stool, called the ova and parasite $(\mathrm{O} \& \mathrm{P})$ examination, is the traditional means of diagnosis (167). One stool sample will allow the detection of 60 to $80 \%$ of infections, 2 stool samples will allow the detection of 80 to $90 \%$, and three stool samples will allow the detection of over $90 \%$ (97, 111). However, in some instances, because of intermittent or low levels of shedding, it is necessary to examine more than three stool samples. The desire for more sensitive and specific, as well as faster and reproducible, diagnostic testing has led to the development of immunoassays. Fecal 


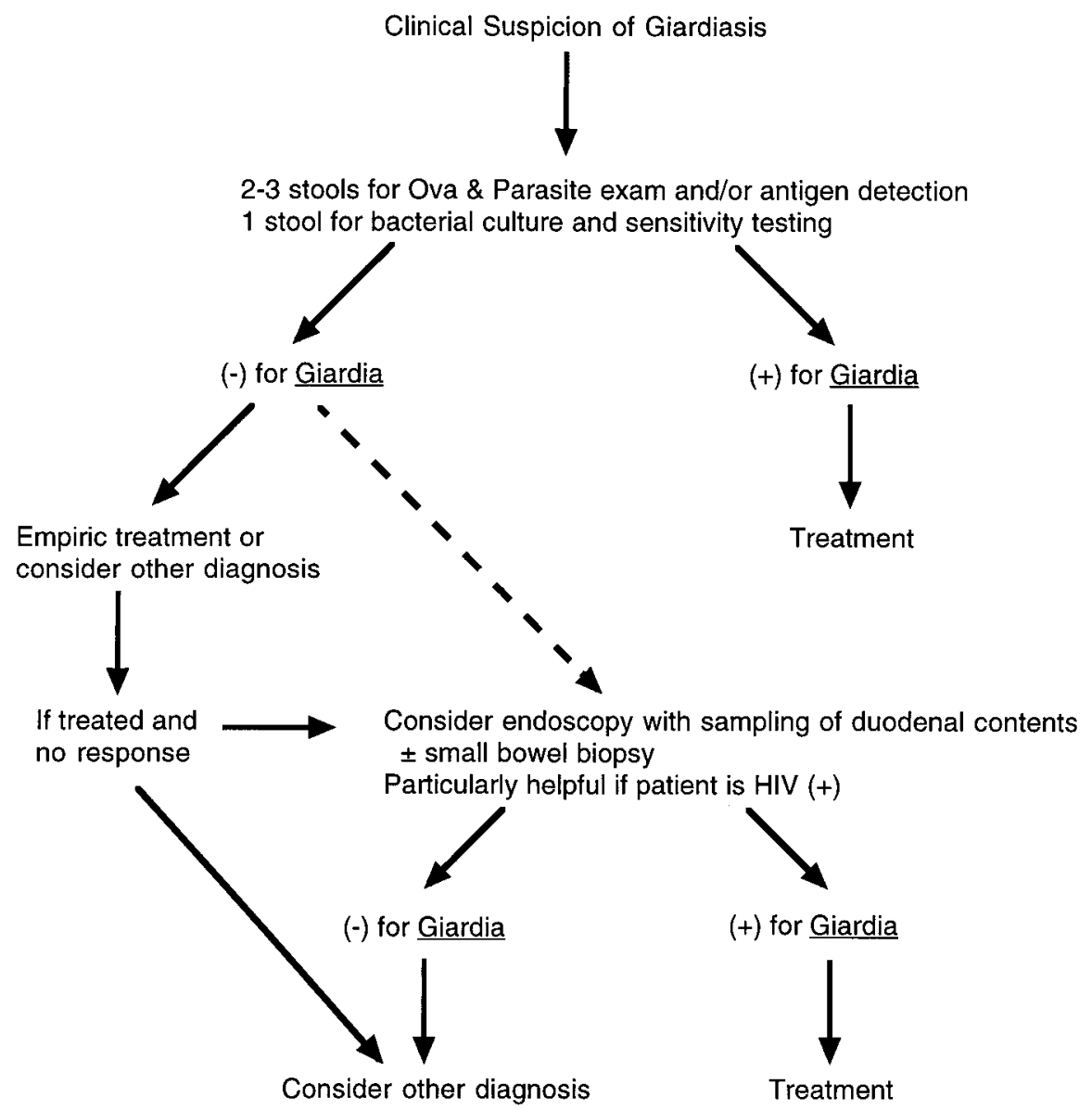

FIG. 2. Outline of the diagnosis and management of suspected cases of giardiasis.

antigen detection using enzyme-linked immunosorbent assays, nonenzymatic immunoassays, or fluorescein-tagged monoclonal antibodies can be superior diagnostic methods to the O\&P examination $(7,89,90,161,262)$. It is particularly helpful in assessing cure or in screening for Giardia infection. However, when other parasites are in the differential diagnosis, a stool sample for O\&P examination should still be ordered. In the unusual patient for whom a diagnosis cannot be made by $O \& P$ examination of stool, endoscopy with duodenal fluid sampling and biopsy may be performed $(82,113,185,256)$. An instance in which this may be helpful is the human immunodeficiency virus-infected patient with diarrhea, whose illness has multiple potential etiologies. Culture and sensitivity testing is available only in research settings $(120,138)$. DNA probes have been generally limited to detection of parasites in water samples $(134,158)$, and serologic testing is most useful in epidemiologic surveys $(118,119,170)$. Figure 2 outlines an approach to the diagnosis and management of suspected cases of giardiasis and is discussed further below (see "Recommendations").

\section{THERAPY OF GIARDIASIS}

When evaluating the clinical efficacy of agents used against Giardia, it is difficult to compare studies. They vary as to entry methodology (whether randomization was done and if treat- ment was blinded or open), population studied (children, adults, symptomatic and/or asymptomatic patients), outcome measures (clinical efficacy and/or stool negativity), and duration of follow-up. Nevertheless, conclusions may be drawn from the studies when viewed as a whole, and statements can be made about the relative efficacy of the agents.

\section{Classes of Agents and Clinical Properties}

Nitroimidazoles. The nitroimidazoles class of agents used to treat G. lamblia infection includes metronidazole, tinidazole, ornidazole, and secnidazole. This class was discovered in 1955 and was found to be highly effective against several protozoan infections (240). Metronidazole [1-( $\beta$-hydroxyethyl)-2-methyl5-nitroimidazole; Flagyl] was determined to be therapeutic against Trichomonas vaginalis and Entamoeba histolytica following its discovery in the late 1950s (67), and in 1962 Darbon et al. reported that it could be used to treat giardiasis (57). Since this discovery, metronidazole and other nitroimidazoles have been used by clinicians as the mainstay of therapy of giardiasis.

Of the nitroimidazoles, the mechanism of killing of Giardia by metronidazole has been the most thoroughly studied. Metronidazole utilizes the anaerobic metabolic pathways present in Giardia. The drug enters the trophozoite, and once it is 
within the cell, electron transport protein ferredoxins from the parasite donate electrons to the nitro group of the drug (223, $238,244)$. The drug becomes "activated" by reduction of this nitro group $(223,238,240)$, and a gradient favoring the intracellular transport of metronidazole is established by this reduction reaction. Reduced metronidazole serves as a terminal electron acceptor which binds covalently to DNA macromolecules $(72,177)$. This results in DNA damage in the form of loss of helical structure, impaired template function, and strand breakage, with subsequent trophozoite death (95). In addition to this effect, metronidazole inhibits trophozoite respiration $(81,189)$. The reductive activation of metronidazole may also lead to toxic radicals, which react with essential cellular components (244). Trophozoites within cysts may be less affected by nitroimidazoles, possibly because of poor penetration of drug through the cyst wall (236). Resistance to metronidazole has been induced in vitro (29). It correlates with decreased activity of parasite pyruvate:ferredoxin oxidoreductase, which is required for reductive activation of nitroimidazoles (239, 247).

Metronidazole is quickly and completely absorbed after oral administration and penetrates body tissues and secretions such as saliva, breast milk, semen, and vaginal secretions (240). The drug is metabolized mainly in the liver and is excreted in the urine (147).

In vitro assays for nitroimidazole drug susceptibility have been performed with G. lamblia since 1980 (112). Using microscopic evaluation of parasite morphology and mobility, Jokipii and Jokipii first demonstrated that metronidazole and tinidazole were effective (129). Subsequently, morphology (13, $166,175)$, growth inhibition $(56,69,94,116,160,225),\left[{ }^{3} \mathrm{H}\right]$ thymidine incorporation $(32,117,164)$, serum killing (114), vitaldye exclusion $(114,235)$, inhibition of adherence $(21,55,79$, $166,192)$, metabolic (228), and colorimetric (133) assays have been employed to measure the in vitro response of the drug to many therapeutic agents. However, as indicated by the variety of assays used, there is no standard for in vitro testing, making it difficult to compare results and apply in vitro findings to the clinical setting.

Of the nitroimidazoles, tinidazole and metronidazole have consistently demonstrated the greatest in vitro activity; tinidazole possesses a slight advantage $(30,32,55,101)$. More highly substituted nitroimidazoles, such as miconazole, clotrimazole, itraconazole, and ketoconazole, were developed for their antifungal activity and are not effective agents against $G$. lamblia (55). Sensitivity to nitroimidazoles can vary depending on the stocks and clones of $G$. lamblia used in testing $(29,31,79,160)$.

In the United States, metronidazole is the only member of the nitroimidazole class available to treat giardiasis; it is also the most common drug used for treatment worldwide. In spite of its widespread and accepted use against Giardia, the U.S. Food and Drug Administration has never approved it for this indication. Clinical trials have employed dosing two and three times daily (usually $250 \mathrm{mg} /$ dose) for 5 to 10 days and shortcourse (1 to 3 days), daily single-dose therapy $(2.0$ or $2.4 \mathrm{~g} /$ dose) (261). In the 5- to 10-day schedules the efficacy ranges from 60 to $100 \%$ in adult and pediatric patients, with a median efficacy in both groups of $92 \%$ (Table 1) (20, 49, 68, 91, 92, 100, $127,132,135,150,151,191,201,202,232,256)$. In general, this schedule is well tolerated, with most side effects involving gastrointestinal upset and metallic taste (Table 2).

The single-dose, short-course treatments (one high dose given daily) were designed to improve compliance without sacrificing efficacy. They have been used in both adults and children. These regimens are generally less efficacious, particularly if only one dose of metronidazole is given. The efficacy of single-dose therapy ranges from 36 to $60 \%$ if the drug is given for 1 day $(16,93,127,130,220,229)$ and rises to 67 to $80 \%$ if the drug is given for 2 days (Table 1) $(127,130,146$; E. Green, D. M. Lynch, J. A. McFadzean, and I. M. Pugh, Letter, Br. Med. J. 2:411-412, 1974). Continuing single-dose treatment for 3 days increases efficacy to the range seen with lowerdose, longer-course therapies (229; Green et al., Letter). The high-dose regimens may also carry more side effects (127).

Children have been included in many of the trials of both long- and short-course therapy, with outcomes similar to those in adults and 80 to $100 \%$ efficacy (median, 94\%) in the 5- to 10-day regimens $(91,100,132,135,186,201,232$; A. RastegarLari and A. Salek-Moghaddam, Letter, J. Trop. Pediatr. 42: 184-185, 1996). Although metronidazole does not come in a standard liquid form, a suspension can be prepared by thoroughly crushing metronidazole tablets, using a drop of glycerin as a lubricant, and suspending the mixture in Cherry Syrup NF (150).

The most common side effects of metronidazole treatment include headache, vertigo, nausea, and a metallic taste in the mouth (Table 2). Nausea occurs in 5 to $15 \%$ of patients given standard multiday courses $(135,151)$. In addition, pancreatitis, central nervous system toxicity at high doses $(144,212)$, and transient, reversible neutropenia have been attributed to metronidazole (147). Patients should be warned to avoid alcohol while taking metronidazole. The inhibition of aldehyde dehydrogenase by metronidazole can cause severe vomiting, flushing, headache, and gastrointestinal pain following alcohol ingestion.

Metronidazole is mutagenic in bacteria and carcinogenic in mice and rats at high doses over long periods (34, 153, 240, 251). However, mutagenicity has never been documented in humans, suggesting that the use of metronidazole is safe in this regard $(23,78,98,212)$. This may, however, mitigate against the short-course high-dose regimens in children.

The finding of therapeutic efficacy with metronidazole spurred investigators to develop and test other nitroimidazole derivatives. The other agents, tinidazole, ornidazole, and secnidazole, each have longer half-lives, making them suitable for single daily-dose therapies (217). One dose of tinidazole (Fasigyn) was successfully used in 1971 in a group of Swedish students who acquired giardiasis during a visit to Russia (11). This single, 2-g dose (or equivalent in children) has consistently proven to have a clinical efficacy of 80 to $100 \%$ with a median efficacy of $92 \%$ (Table 1) $(16,126,130,131,146,151$, 193, 222, 229, 261; Z. Farid, N. A. El Masry, W. F. Miner, and A. Hassan, Letter, Lancet ii:721, 1974; T. Pettersson, Letter, Br. Med. J. 1:395, 1975) and is far superior to metronidazole when single-dose regimens are directly compared (93, 130, 229, 261). There is also improved compliance with this dosing schedule. The recommended dosing for pediatric populations is usually $50 \mathrm{mg} / \mathrm{kg}$ for a single dose (Table 2) (82, 193, 232, 256), and the drug is available in a liquid suspension. 
TABLE 1. Efficacy of anti-Giardia drugs in adult and pediatric infection ${ }^{a}$

\begin{tabular}{|c|c|c|c|}
\hline Drug & $\operatorname{Dose}^{b}$ & Median efficacy $(\%)^{c}$ & Efficacy range $(\%)$ \\
\hline Metronidazole & $\begin{array}{l}500-750 \mathrm{mg} / \text { day } \times 5-10 \text { days } \\
2.0-2.4 \mathrm{~g}, \text { single dose } \\
2.0-2.4 \mathrm{~g}, \mathrm{q} . \mathrm{d} . \times 2 \text { days } \\
2.0-2.4 \mathrm{~g}, \mathrm{q} . \mathrm{d} . \times 3 \text { days } \\
15-22.5 \mathrm{mg} / \mathrm{kg} / \text { day } \times 5-10 \text { days }^{d}\end{array}$ & $\begin{array}{l}88 \\
48 \\
71 \\
94\end{array}$ & $\begin{array}{l}60-95 \\
36-60 \\
67-80 \\
93-100 \\
80-100\end{array}$ \\
\hline Tinidazole & $\begin{array}{l}300 \mathrm{mg} / \text { day } \times 7 \text { days } \\
1.0-2.0 \mathrm{~g} \text {, single dose } \\
50 \mathrm{mg} / \mathrm{kg} \text {, single dose }{ }^{d}\end{array}$ & $\begin{array}{l}87 \\
92 \\
91\end{array}$ & $\begin{array}{l}74-100 \\
86-100 \\
80-96\end{array}$ \\
\hline Ornidazole & $\begin{array}{l}1.0-2.0 \mathrm{~g}, \text { single dose } \\
40-50 \mathrm{mg} / \mathrm{kg}, \text { single dose }{ }^{d}\end{array}$ & & $\begin{array}{l}96-100 \\
92-100\end{array}$ \\
\hline Secnidazole & $\begin{array}{l}2.0 \mathrm{~g} \text {, single dose } \\
30 \mathrm{mg} / \mathrm{kg}, 1 \text { or } 2 \text { doses }^{d}\end{array}$ & & $\begin{array}{l}86-100 \\
88-100\end{array}$ \\
\hline Quinacrine & $\begin{array}{l}300 \mathrm{mg} / \text { day } \times 5-7 \text { days } \\
6-8 \mathrm{mg} / \mathrm{kg} / \text { day } \times 5-10 \text { days }^{d}\end{array}$ & & $\begin{array}{l}95-100 \\
92-95\end{array}$ \\
\hline Furazolidone & $\begin{array}{l}400 \mathrm{mg} / \text { day } \times 7-10 \text { days } \\
8 \mathrm{mg} / \mathrm{kg} / \text { day } \times 7-10 \text { days }^{d}\end{array}$ & 92 & $\begin{array}{l}80-85 \\
81-96\end{array}$ \\
\hline Albendazole & $\begin{array}{l}200-800 \mathrm{mg} / \text { day } \times 1-3 \text { days } \\
200-400 \mathrm{mg} / \text { day } \times 5-7 \text { days }\end{array}$ & & $\begin{array}{l}24-81 \\
94-100\end{array}$ \\
\hline Paromomycin & $10-50 \mathrm{mg} / \mathrm{kg} /$ day or $1,500 \mathrm{mg} /$ day $\times 5-10$ days & & $55-88$ \\
\hline Bacitracin zinc & $240,000 \mathrm{U} /$ day $\times 10$ days & & 95 \\
\hline
\end{tabular}

${ }^{a}$ Efficacy is based on studies that may vary in design, entry methodology, or outcome measure. When separate pediatric populations were studied, they are designated. See the text for references.

${ }^{b}$ Doses are total daily amounts, which may or may not have been given in divided doses. Actual treatment recommendations are presented in Table 2. q.d., once a day.

${ }^{c}$ Median efficacy is given when the results of four or more studies are included.

${ }^{d}$ Pediatric population only.

Adverse effects reported with tinidazole are not as common as with metronidazole but do include bitter taste, vertigo, and gastrointestinal upset (Table 2) (130, 131; Pettersson, Letter). Tinidazole is not available in the United States, but travel health providers recommend that some travelers, particularly long-term travelers or overland trekkers in Asia, purchase the drug upon arrival at their country of destination and take it in the event of acquiring giardiasis (113).

Another nitroimidazole derivative which is also not available in the United States is ornidazole. There have been fewer studies with ornidazole, but it has excellent efficacy when given over several days and efficacy similar to tinidazole (92 to 100\%) when given as a single dose $(19,131,145,220,232,261)$. Single-dose ornidazole ( $40 \mathrm{mg} / \mathrm{kg}$ ) has also been given to children, with obvious benefits regarding compliance and cost (39, 186). In one study the drug was given intravenously and was associated with increased side effects, making the investigators reluctant to recommend routine use of this drug in children until large-scale studies of recurrence, carcinogenicity and side effects are completed (39).

Secnidazole, a long-acting 5-nitroimidazole derivative, has been used but is not available in the United States. Similar to tinidazole and ornidazole, secnidazole is usually given as a single dose. The most common regimen is $2 \mathrm{~g}$ in adults and 30 $\mathrm{mg} / \mathrm{kg}$ in children (95). Clinical studies demonstrate efficacy rates of over $85 \%$ with the single dose in adults (49; R. Baqai, H. Qureshi, and S. J. Zuberi; Letter, J. Pak. Med. Assoc.
$45: 288,1995)$, and in children, this dosing is as effective as a 7 to 10-day course of metronidazole (100; Rastegar-Lari and Salek-Moghaddam, Letter). The drug is rapidly and completely absorbed, has a half-life of 17 to 29 hours, and is metabolized via oxidation in the liver (95). Adverse effects have been reported, most notably gastrointestinal disturbance (nausea, anorexia, and abdominal pain) and dizziness, but usually do not require discontinuation of the drug.

Quinacrine. Quinacrine (Atabrine) was first introduced as an antimalarial agent in 1930, following the work of Kikuth, and became the antimalarial of choice for allied troops in World War II because of its greater availability and better tolerance compared with quinine (240). After the war, it soon became an important agent against $G$. lamblia, with a clinical efficacy of $90 \%$ or more $(20,52,105,255)$. However, with a U.S. market limited to the treatment of Giardia, the use of quinacrine declined, and its production in the United States was discontinued in 1992, although it may still be obtained through alternative sources (Table 2).

The antiprotozoal mechanism of quinacrine is not fully elucidated. The drug intercalates readily with G. lamblia DNA, and it is this interaction which is thought to cause an inhibition of nucleic acid synthesis (240). The differing relative quinacrine uptake rate between human and G. lamblia cells may be responsible for the selective toxicity of the drug (236). In vitro, quinacrine reduces cyst viability and excystation rates (179, 189). Resistance has been induced in vitro, and in one study it 
TABLE. 2. Recommended dosing and adverse effects of anti-Giardia drugs

\begin{tabular}{|c|c|c|c|}
\hline Drug & Adult dose ${ }^{f}$ & Pediatric dose & Adverse effects \\
\hline Metronidazole $^{a}$ & $250 \mathrm{mg}$ t.i.d. $\times 5-7$ days & $5 \mathrm{mg} / \mathrm{kg}$ t.i.d. $\times 5-7$ days & $\begin{array}{l}\text { Headache, vertigo, nausea, metallic taste, } \\
\text { urticaria } \\
\text { Disulfiram-like reaction with alcohol } \\
\text { ingestion } \\
\text { Rare: pancreatitis, central nervous system } \\
\text { toxicity, reversible neutropenia, peripheral } \\
\text { neutropathy, T-wave flattening with } \\
\text { prolonged use } \\
\text { Mutagenic/carcinogenic? }\end{array}$ \\
\hline
\end{tabular}

$\begin{array}{lll}\text { Tinidazole }^{b} & 2 \mathrm{~g}, \text { single dose } & 50 \mathrm{mg} / \mathrm{kg}, \text { single dose }(\mathrm{max}, 2 \mathrm{~g}) \\ \text { Ornidazole }^{c} & 2 \mathrm{~g}, \text { single dose } & 40-50 \mathrm{mg} / \mathrm{kg}, \text { single dose }(\mathrm{max}, 2 \mathrm{~g}) \\ \text { Quinacrine }^{c} & 100 \mathrm{mg} \text { t.i.d. } \times 5-7 \text { days } & 2 \mathrm{mg} / \mathrm{kg} \text { t.i.d. } \times 7 \text { days }\end{array}$

Furazolidone $^{d} \quad 100 \mathrm{mg}$ q.i.d. $\times 7-10$ days $\quad 2 \mathrm{mg} / \mathrm{kg}$ q.i.d. $\times 10$ days

\begin{tabular}{|c|c|c|}
\hline Paromomycin $^{a}$ & $500 \mathrm{mg}$ t.i.d. $\times 5-10$ days & $30 \mathrm{mg} / \mathrm{kg} /$ day in 3 doses $\times 5-10$ days \\
\hline Albendazole $^{a}$ & $400 \mathrm{mg}$ q.d. $\times 5$ days & $15 \mathrm{mg} / \mathrm{kg} / \mathrm{day} \times 5-7$ days $(\max , 400 \mathrm{mg})$ \\
\hline Bacitracin zinc $^{e}$ & 120,000 U b.i.d. $\times 10$ days & Not tested in children under $10 \mathrm{yr}$ \\
\hline
\end{tabular}

was correlated with decreased uptake of the drug (246). Quinacrine is rapidly absorbed from the intestinal tract and is widely distributed in body tissues.

Although results differ, depending on the in vitro sensitivity testing assay used, metronidazole and furazolidone have been shown to be slightly more potent than quinacrine $(30,32,55$, 94). However, in other studies the in vitro efficacies of quinacrine and metronidazole are the same $(21,117,164)$. Some of this difference may be related to the greater variation in sensitivity to quinacrine than to metronidazole or furazolidone between clones of Giardia (31).

Clinically, quinacrine is very effective, with studies establishing its efficacy over 5 to 10 days at about $95 \%$ (Table 1) (20, $135,220,255)$. Some researchers consider the drug to be the most efficacious of any of the anti-Giardia therapeutics (256). Dosing is usually $100 \mathrm{mg}$ three times a day over 5 to 7 days for adults and $6 \mathrm{mg} / \mathrm{kg} /$ day in three divided doses over 5 to 7 days for children (Table 2) (150).

Side effects have precluded many clinicians from using quinacrine, particularly in children (Table 2). A bitter taste, along with vomiting, has been reported in up to $28 \%$ of study participants $(20,52)$, and led to a lower efficacy in children younger than 5 years (52), probably due to low compliance. Yellow/orange discoloration of the skin, sclerae, and urine affects 4 to $5 \%$ of those taking quinacrine, beginning about 1 week after starting treatment, and can last up to 4 months after discontinuation of therapy. Other common side effects include nausea, vomiting, headache, and dizziness (254). Drug-induced psychosis is uncommon, and exfoliative dermatitis and quinacrine-induced retinopathy are rare (82). Quinacrine can exacerbate psoriasis, and in glucose-6-phosphate dehydrogenase (G6PDH)-deficient individuals, it can precipitate hemolysis. It is contraindicated in pregnancy due to a possible link with spina bifida and renal agenesis. It has never been demonstrated to be carcinogenic, even though it has a mechanism of action of binding to DNA.

Furazolidone. Furazolidone (Furoxone) is one of the thousands of nitrofuran compounds created since the class was discovered in the 1940s (143). It is effective against many bacteria including Klebsiella spp., Clostridium spp., Escherichia 
coli, Campylobacter spp., and Staphylococcus aureus. As early as the 1950s, furazolidone was being used in the treatment of giardiasis (253). It is approved for use in the United States and remains an important therapeutic agent worldwide. Of the common anti-Giardia therapeutics, it is the only one available in a liquid suspension in the United States; therefore, its use has been advocated in pediatric populations (150).

The mechanism of action of furazolidone against $G$. lamblia, like many of the antiparasitics, is not completely explained. The drug undergoes reductive activation in the $G$. lamblia trophozoite, but, unlike metronidazole, reduction possibly occurs via an NADH oxidase $(38,244)$. Its killing effect correlates with the toxicity of reduced products, which can damage important cellular components including DNA. Resistance to furazolidone may be correlated with decreased entry of drug (246) or with increased levels of thiol-cycling enzymes, which can defend against toxic radicals (249). The drug is readily absorbed via the gastrointestinal tract and is metabolized rapidly in tissues, leading to low concentrations in serum and urine (143).

In in vitro susceptibility testing, furazolidone performs comparably to metronidazole and has consistently demonstrated the highest activity of the nonimidazoles $(32,55,101)$; it is more active than quinacrine (30).

Clinical studies using furazolidone are numerous and have been completed with a wide range of subjects, doses, and administration schedules. Although its efficacy has generally been considered to be slightly lower than those of metronidazole and quinacrine, curative rates between 80 and $96 \%$ have been reported for 7- to 10-day courses (Table 1) (20, 52, 91, $151,178,191,201,255)$. It is when the drug is given for only 5 days that efficacy falls off considerably $(151,178)$. It is given as four doses per day in both adults (100 mg per dose) and children $(1.5 \mathrm{mg} / \mathrm{kg}$ ) (Table 2$)$. In the pediatric suspension, two tablespoonfuls substitute for a 100-mg tablet.

About $10 \%$ of patients report gastrointestinal symptoms such as nausea, vomiting, and diarrhea (Table 2) (150, 256). Other adverse effects can include a brown discoloration of the urine; hemolysis can occur in G6PDH-deficient patients. The drug has a monoamine oxidase (MAO) inhibitory effect and should never be given concurrently to individuals already taking MAO inhibitors. There have been rare reports of disulfiram-like reactions when it is taken with alcohol (164b). A furazolidone-induced manic episode in a patient infected with human immunodeficiency virus has been reported (73). Furazolidone is also contraindicated in infants younger than 1 month of age, who could develop hemolytic anemia because of their normally unstable glutathione. Finally, the drug is mutagenic in bacteria and has been demonstrated to cause mammary tumors in rats and pulmonary tumors in mice when given in chronic high doses. However, the implication of this finding for humans is not known and has not been adequately addressed $(143,164 b, 236)$. When treating pediatric populations, the advantages of its minimal adverse effects and the availability of a liquid suspension must be weighed against the need for frequent dosing over a 10-day treatment period.

Benzimidazoles. Two members of the benzimidazole class of therapeutics, albendazole (Albenza) and mebendazole (Vermox), have been used to treat G. lamblia infection (155). Clinical and in vitro efficacy studies have produced different results as to their effectiveness. However, a comparatively benign side effect profile, combined with proven efficacy against many helminths, renders them promising for treatment $(208,250)$.

The benzimidazoles exert their toxic effect on Giardia in part by binding to the $G$. lamblia $\beta$-tubulin cytoskeleton $(71,175$, 209). This binding causes both inhibition of cytoskeleton polymerization and impaired glucose uptake (250). Although the exact binding site on the cytoskeleton has not been determined, it is postulated that a benzimidazole-colchicine site interaction may play a role $(51,166,236)$. The benzimidazoles are poorly absorbed from the gastrointestinal tract, although this can be improved with the coingestion of a fatty meal. The systemic effect of albendazole is due to its primary metabolite, albendazole sulfoxide, which is rapidly formed in the liver following absorption (3). Excretion by the kidneys is negligible.

In vitro susceptibility testing of $G$. lamblia to the benzimidazoles is limited in comparison to the susceptibility of the parasite to the nitroimidazoles or quinacrine. Nevertheless, studies demonstrate a considerable in vitro effect $(79,175,208$, 209). One report showed that both albendazole and mebendazole were 30- to 50-fold more active than metronidazole and 4to 40 -fold more active than quinacrine in vitro (71). Another demonstrated that the ability of albendazole to affect trophozoite morphology, adherence, and viability was far greater than that of metronidazole or tinidazole (166). However, their variable clinical efficacy demonstrates the discordance between in vitro testing and in vivo activity. Resistance to albendazole can be induced in vitro (154) and correlates with changes in the parasite cytoskeleton (243). Other benzimidazoles such as nocodazole, oxfendazole, thiabendazole, and fenbendazole have also demonstrated some in vitro efficacy (236).

Clinical trials have been limited to albendazole and mebendazole, with mixed results. Hall and Nahar reported equal curative efficacy of albendazole and metronidazole in children when albendazole was given for 5 days but not when it was given in single or 3-day dosing (Table 1) (104). A decreased efficacy of albendazole when given for 3 days or less was also documented by Kollaritsch et al. in travelers with giardiasis (137), by Pungpak et al. in children and adults (198), and by Pengsaa et al. in children (193). Improved efficacy was seen in other patients when the drug was given for 5 days $(171,207$, 214) or 7 days (198). The exception to the need for longer treatment courses was seen in one study in which a single dose was administered (68). An albendazole-metronidazole combination was $100 \%$ effective in 20 patients with metronidazoleresistant giardiasis who had failed three to five courses of standard oral metronidazole therapy (44).

Treatment with mebendazole has resulted in widely divergent clinical results. Al-Waili reported over $90 \%$ efficacy in two studies in children $(8,9)$. However, other studies in both pediatric and adult populations have not shown equal success but instead have shown effectiveness in $80 \%$ (211) and in $60 \%$ or less (39, 92, 132; L. di Martino, A. Nocerino, and M. Pettoello Mantovani, Letter, Trans. R. Soc. Trop. Med. Hyg. 85:557$558,1991)$, as well as a failure to decrease the prevalence rates of Giardia when mebendazole was used in mass treatment of helminths (219). Because of this discrepancy, most interest has focused on albendazole.

The dosage in adults is usually $400 \mathrm{mg}$ per day for 5 days for albendazole and 200 to $400 \mathrm{mg}$ per day for 5 to 10 days for 
mebendazole (Table 2). The usual dosage in children is 15 $\mathrm{mg} / \mathrm{kg}$ per day for 5 to 7 days. Both drugs are available in suspension. One advantage of using albendazole in children is its efficacy against many helminths, allowing effective treatment of multiple intestinal parasites $(207,208)$. Another advantage is its relative lack of side effects. However, with shortterm use, it may cause gastrointestinal problems of anorexia and constipation. Long-term, high-dose use of albendazole, such as when it is used for larval cestode infections, has caused reversible neutropenia and elevated hepatic enzyme levels (3, $155,258)$. Albendazole is contraindicated in pregnancy, due to possible teratogenicity (pregnancy category $\mathrm{C}$ ), but animal studies have shown no increase in carcinogenic incidence.

Paromomycin. Paromomycin (Humatin), a member of the aminoglycoside family, was first isolated in 1956. It is indicated for the treatment of Entamoeba histolytica and Trichomonas and has been proposed as a treatment for G. lamblia in resistant infections and during pregnancy $(113,140)$. Paromomycin is poorly absorbed from the intestinal lumen; even large-dose oral administrations achieve only minimal concentrations in the blood and urine of patients with normal renal function (140). Paromomycin inhibits G. lamblia protein synthesis by interfering with the $50 \mathrm{~S}$ and $30 \mathrm{~S}$ ribosomal subunits (the parasite rRNA has an unusual size and sequence) and causing misreading of mRNA codons (69).

In vitro susceptibility testing demonstrates that paromomycin has activity against $G$. lamblia, but the activity is generally lower than that of the nitroimidazoles, quinacrine, or furazolidone $(30,101)$. However, because of poor intestinal absorption, it compensates for its low antiprotozoal activity by achieving high levels in the gut. In a rat model, the drug showed efficacy (15).

Clinical studies are limited, and therapeutic efficacy ranges from 55 to nearly $90 \%$ (Table 1$)(47,63,140,191,218)$. The usual dose is $500 \mathrm{mg}$ three times per day for 10 days in adults and 25 to $30 \mathrm{mg} / \mathrm{kg} /$ day (divided into three doses) in children (Table 2).

As with other aminoglycosides, if absorbed systemically paromomycin can cause ototoxicity and nephrotoxicity. However, it may be less ototoxic than other aminoglycosides (142), and with limited systemic absorption, toxicity should not be a concern in persons with normal kidneys. However, it should be used with caution in those with impaired renal function.

Bacitracin zinc. The search for alternative, effective antiGiardia therapeutics has led investigators to consider bacitracin. Bacitracin was first isolated in 1945 from a strain of $\mathrm{Ba}$ cillus and was used systemically against severe staphylococcal infections until 1960, when its toxicity and the availability of other antibiotics restricted it to mainly topical use (141). Zinc was added to the bacitracin complex to promote stability. Bacitracin exerts its effect in bacteria by interfering with a dephosphorylation step in cell membrane synthesis. Following demonstrated in vitro effectiveness against $E$. histolytica and Trichomonas, bacitracin zinc was tested against Giardia in vitro and found to be active $(12,13)$.

A clinical trial by Andrews et al. used twice-daily dosing over 10 days and compared the effectiveness of 120,000 $\mathrm{U}$ of bacitracin zinc, $120,000 \mathrm{U}$ of bacitracin, 120,000 $\mathrm{U}$ of neomycin, and $60,000 \mathrm{U}$ of bacitracin zinc in combination with $60,000 \mathrm{U}$ of neomycin (14). Cure rates of $95 \%$ for bacitracin zinc, $88 \%$ for either bacitracin or the bacitracin zinc-neomycin combination, and $86 \%$ for neomycin were demonstrated. Adverse effects were limited to a small number of patients who experienced diarrhea, abdominal discomfort, constipation, and nausea. Children younger than 10 years were excluded from the study.

The disadvantages of using bacitracin zinc include a potential for nephrotoxicity with prolonged oral dosing and gastrointestinal disturbance. Furthermore, compliance can be affected by the 10-day dosing period, and the formulations used by Andrews in their study are not readily available. Although bacitracin zinc is promising, more investigation is needed before it can gain wide acceptance as an agent against G. lamblia.

Emerging and experimental therapeutics. A wide variety of chemotherapeutic agents including rifampin, bithionol, dichlorophene, hexachlorophene, pyrimethamine, sodium fusidate, chloroquine, and mefloquine have demonstrated in vitro activity against Giardia (81, 84, 233). Lipophilic tetracyclines, such as doxycycline, are highly active in vitro; however, their clinical efficacy is limited, perhaps because of their rapid absorption from the intestine (70). Certain pentamidine analogs, as well as azithromycin, have in vitro activity comparable to that of metronidazole $(25,33)$.

Nitazoxanide, a 5-nitrothiazole derivative with broad-spectrum activity against protozoa, helminths, and some bacteria has shown limited efficacy in adults and children in Mexico (71\% [213] and 78\% [211] effectiveness, respectively) and in a few AIDS patients in Mali (64). It has been given in a dose of 100 to $500 \mathrm{mg}$ twice daily for 3 to 7 days.

Studies using a rat model have demonstrated the efficacy of ivermectin under specific conditions (260). Disulfiram, a zinc finger-active compound used for the treatment of alcoholism in humans, shows significant cure rates and decreased parasitic burdens in a mouse model of giardiasis (180).

In an ethnobotanical survey of the anti-Giardia gastrointestinal remedies employed by the Luo tribes of East Africa, methanolic extracts of 21 of the 36 taxa studied were lethal to or inhibited the growth of G. lamblia in vitro (124). Geranium nivem extracts have also shown in vitro activity (45). The immunomodulatory herbal drug Pippali rasayana, often prescribed for the treatment of worm infections and chronic dysentery in India, achieved a $98 \%$ cure of murine infection with G. lamblia (6). Extracts of Piper longum fruit were effective in a mouse model of infection (241).

Proposlina, a bee glue preparation, demonstrated a $60 \%$ parasitologic cure rate 1 week after treatment was completed among 48 adults in Cuba $(172,261)$. In a patient with metronidazole-resistant Giardia infection, the $\beta$-adrenergic antagonist DL-propranolol, given in a dose of $40 \mathrm{mg}$ three times a day with $400 \mathrm{mg}$ of metronidazole three times a day for 10 days, cleared infection, demonstrating clinical efficacy in humans (197). In vitro studies demonstrate that propranolol exerts its effect by inhibiting the motility and growth of the protozoan, most probably due to the membrane-stabilizing activity of the drug (85). However, further studies with DL-propranolol and the related compound D-propranolol are needed before they can be recommended as anti-Giardia agents.

Immunoprophylactic strategies to prevent or treat giardiasis have generally not been effective (87). Passive transfer of antiGiardia immune serum did not facilitate parasite clearance in 
murine giardiasis $(76,242)$. Although patients with common variable immunodeficiency do have symptomatic and prolonged infection with Giardia antiparasitic therapy is required to control their infection $(106,216)$. Breast milk can be cytotoxic to Giardia via free fatty acids which are generated from milk triglycerides by the action of a bile salt-stimulated lipase (204). Also, breast feeding may confer some protection to suckling infants $(176,183)$; however the approach of providing enteral anti-Giardia antibody has not been studied.

\section{Special Situations}

Pregnancy and lactation. The management of symptomatic G. lamblia infection during pregnancy is a challenge for the clinician because no therapeutic agent combines optimal efficacy and safety. Women who are asymptomatic, have mild disease, or are in their first trimester should usually avoid being treated. However, women in whom adequate hydration and nutritional status cannot be maintained should be treated, even in the first trimester.

Metronidazole, which rapidly enters the fetal circulation after absorption by the mother, has demonstrated mutagenicity in bacteria and carcinogenicity in mice and rats $(34,36,153$, $240,251)$. While this information raises concern about the use of the drug during pregnancy, carcinogenicity has not been demonstration in humans $(23,24,78,98,212)$, nor has there been teratogenicity in rodents (164a). Metronidazole has been used extensively during pregnancy (pregnancy category B), primarily for therapy of trichomoniasis in 7- to 10-day courses (42). The results regarding safety to the fetus are conflicting $(36,42,107,212,215,218)$. One retrospective study of 1,469 women who took metronidazole in pregnancy, with 206 using the drug in the first trimester, found no evidence of congenital abnormality (26). However, the Collaborative Perinatal Project, including over 50,000 mother-child pairs, demonstrated that first-trimester exposure to metronidazole in 31 women showed a possible association with malformations (107). A meta-analysis of seven studies, prospectively monitoring 253 mother-infant pairs and retrospectively monitoring 1,083 pairs, found no increased risk of fetal malformation in association with first-trimester use of metronidazole (42), with one report estimating a relative risk of 0.92 for birth defects (215). On balance, there may be a slightly increased risk when using metronidazole during the first trimester, and thus its use should be avoided during this period. High-dose ( $\geq 2.0 \mathrm{~g})$, short-course regimens should not be given during pregnancy.

Metronidazole is actively excreted in breast milk in concentrations similar to those in plasma. The American Academy of Pediatrics (AAP) recommends giving a single 2-g dose in nursing mothers, followed by discontinuation of nursing for 12 to $24 \mathrm{~h}(10,36)$. The AAP also recommends that mothers taking tinidazole discontinue nursing for the same time period as those taking metronidazole (10). However, metronidazole is approved for use in children for therapy of amebiasis and is used in children for therapy of anaerobic infections, so it would seem that the small amount secreted in breast milk would not be deleterious. Also, since single, high-dose regimens of metronidazole have poor efficacy and would be expected to lead to higher levels in breast milk, these findings favor traditional treatment with lower doses over 5 to 7 days.
Paromomycin is generally considered safe because it is poorly absorbed from the intestine and excreted almost $100 \%$ unchanged in the feces. Therefore, little if any of the drug will reach the fetus. However, it is not as effective as metronidazole or quinacrine. In addition, no clinical trials have addressed the effects of high serum concentrations of paromomycin during pregnancy. Nevertheless, paromomycin has been used successfully to eradicate $G$. lamblia infection in the gravid patient and is an important agent to consider during the first trimester, when metronidazole should not be used $(140,218)$. Paromomycin should also be safe in nursing mothers. A study in ewes showed only a $0.018 \%$ drug recovery rate in breast milk for the $12 \mathrm{~h}$ following parenteral administration $(36,263)$. The AAP does designate streptomycin and kanamycin, aminoglycoside relatives of paromomycin, to be compatible with breast feeding (10).

One expert on giardiasis has espoused quinacrine treatment in pregnant patients due to its high cure rate (256). While the drug is very effective, its slow excretion from the body and proven teratogenicity in rats make it a suboptimal choice for treatment in pregnancy. Although quinidine and quinine are compatible with breast-feeding, no information regarding the safety of quinacrine for the breast-fed child was available (10).

Furazolidone is not recommended for the pregnant patient. Although it is efficacious, its has caused mammary tumors in mice and mutations in bacteria, which should deter the physician from using it in this setting (164b). Its safety for breast-fed children is not known. Albendazole is considered a pregnancy category $\mathrm{C}$ agent, and has been teratogenic in rats and rabbits, although there is little experience of its effects in pregnant women.

Asymptomatic infection. On a global basis, most persons infected with $G$. lamblia are asymptomatic or minimally symptomatic. Treating asymptomatic patients, particularly children, is controversial, and there are several factors to consider before initiating therapy. The setting of the infection plays a key role in the decision. In areas where G. lamblia is endemic, treatment may not be desirable because the children are likely to become rapidly reinfected following treatment $(96,231)$. If Giardia contributes to failure of growth and development (86, $163,227)$, treatment, even though reinfection may occur, might allow catch-up growth (103) and might be worth the cost and effort. A drug such as albendazole, which would also treat nematode infections, might be useful in these settings; however, the requirement for 5-day dosing would make it difficult to complete therapy in many situations.

In conditions in which the child's nutritional baseline is excellent, such as in day care centers in the developed world, asymptomatic carriers may not always need therapy (5, 121, 195, 203, 221, 237). However, it should be noted, that aymptomatically infected children may excrete Giardia for months (195), carry it home to family members and thus initiate infection in the household, and even help maintain high levels of Giardia infection in a community $(4,196,224$; G. D. Overturf, Editorial, Clin. Infect. Dis. 18:764-765, 1994). It is not uncommon for a mother of a young child in day care to become symptomatic with giardiasis, identifying the presence in the household of Giardia which has been introduced by the asymptomatic child. If there is recurrent diarrhea attributed to $\mathrm{Gi}$ ardia in day care which cannot be controlled by improved 
hygiene and by treatment and exclusion of children who are symptomatic, consideration can be given to screening and treating all the children in the day care setting $(5,18,230)$.

If Giardia is detected in the stool and there is little likelihood of reinfection, such as in a returned traveler, treatment can be given. In the household, if one member is symptomatic and there is the possibility that fecal-oral spread has occurred within the family or that there is a common source of infection, all family members should be screened and treated so that reinfection will not occur.

Another factor to consider in deciding whether to treat asymptomatic carriers is the consequences of transmission of infection if the carrier is not treated, e.g., infection in food handlers $(169,199)$. This group should be treated to prevent food-borne outbreaks.

Resistance and relapse. Treatment failures have been reported with all of the common anti-Giardia agents including metronidazole, quinacrine, furazolidone, and albendazole. However, it is important for the clinician faced with recurrence of symptoms after therapy to differentiate between actual drug resistance, cure followed by reinfection, and post-Giardia lactose intolerance. Therefore, the first step is to document true, persistent infection by sending a stool sample for O\&P examination or Giardia antigen detection. If the sample is positive, a careful exposure history should provide information about the likelihood of reinfection, and reinfected individuals should respond to the original therapeutic agent. Reinfection would be common in regions of endemicity around the world and in situations of poor fecal-oral hygiene. If a patient has become reinfected, risk factors should be identified and the patient should be counseled regarding proper hygiene and prevention measures.

Post-Giardia lactose intolerance is the most common of the disaccharidase deficiencies associated with giardiasis and may occur in 20 to $40 \%$ of patients (65). Thus, if the stool is negative for Giardia, a trial of avoiding lactose-containing foods and liquids should be instituted. This syndrome may take several weeks to resolve.

True treatment failure could mean infection with a drugresistant isolate of Giardia. Resistance to most anti-Giardia agents has been documented or induced in vitro (29, 154, 245-247), and multiple, genotypically different clones of $G$. lamblia with different drug class susceptibilities have been found in the human duodenum $(46,81,160,248)$. However, there has not been a consistent correlation between in vitro resistance or sensitivity and clinical failure or success $(43,160$, $164,225,249)$, still leaving open the question of true parasite resistance.

Clinically resistant strains have been treated with longer repeat courses or higher doses of the original agent $(91,165$, 178). However, the most efficacious means of eradicating these infections seems to involve using a drug from a different class to avoid potential cross-resistance $(52,92)$. An initial switch to a drug of a different class may not always be effective as demonstrated in two French patients who failed albendazole treatment following two courses of metronidazole but did respond to quinacrine (P. Brasseur and L. Favennec, Letter, Parasite 2:422, 1995). Combination regimens using metronidazole-albendazole, metronidazole-quinacrine, or other active drugs or giving a nitroimidazole plus quinacrine for courses of at least 2
TABLE 3. Recommendations for therapy of giardiasis

\begin{tabular}{|c|c|}
\hline Clinical scenario & Drug and duration of treatment ${ }^{a}$ \\
\hline \multicolumn{2}{|l|}{ Symptomatic infection, USA } \\
\hline Adult and pediatric & Metronidazole for 5-7 days \\
\hline Alternatives & $\begin{array}{l}\text { Furazolidone for } 7-10 \text { days } \\
\text { or quinacrine for } 5-7 \text { days } \\
\text { or albendazole for } 5-7 \text { days }\end{array}$ \\
\hline \multicolumn{2}{|l|}{ Symptomatic infection, overseas } \\
\hline Adult and pediatric & $\begin{array}{l}\text { Tinidazole (single dose) or } \\
\text { ornidazole (single dose) }\end{array}$ \\
\hline \multicolumn{2}{|l|}{ Pregnancy } \\
\hline First trimester & Paromomycin for 5-10 days \\
\hline Second and third trimesters & $\begin{array}{l}\text { Paromomycin for } 5-10 \text { days } \\
\text { or metronidazole for } 5-7 \\
\text { days }\end{array}$ \\
\hline Resistant infection or relapse & $\begin{array}{l}\text { Drug of different class or } \\
\text { combination nitroimidazole } \\
\text { plus quinacrine for } 2 \text { wk or } \\
\text { more }\end{array}$ \\
\hline
\end{tabular}

${ }^{a}$ For drug dosing, see Table 2.

weeks have proven successful against refractory infection (44, 182a, 197, 225, 234). On occasion, several different combinations or approaches will be necessary to effect cure.

In cases of giardiasis in which alternative therapy is not effective, other possibilities should be considered, such as the presence of immunologic deficiency. Chronic giardiasis in patients with hypogammaglobulinemia is well recorded $(106,108$, 216) and can be difficult to treat, often requiring prolonged courses of therapy. Although Giardia is seen in homosexual men who engage in oral-anal sexual practices $(162,200,226)$, illness may often be neither severe nor prolonged (148). Nevertheless, in AIDS patients with severe giardiasis, prolonged or combination therapy may be necessary (182a).

\section{RECOMMENDATIONS}

An approach to the diagnosis and management of suspected giardiasis is illustrated in Fig. 2 and discussed in more detail above (see "Background"). If stools are negative, an empiric course of therapy can be given; however, an alternative diagnosis should be considered. If there is no response to therapy in stool-negative cases, invasive testing by endoscopy can be performed to help determine the diagnosis, particularly if the patient is immunocompromised.

When treatment is carried out, the agents of choice are listed in Table 3 and the dosages are given in Table 2. The most effective agents for therapy of giardiasis are single doses of tinidazole or ornidazole, 5 to 7 days of quinacrine, and 5 to 7 days of metronidazole. Tinidazole and ornidazole are not approved or available in the United States. Production of quinacrine has been discontinued, but it still may be obtained on a limited basis; however, it has significant side effects, particularly in children. Therefore, the treatment of choice in the United States for both adults and children is metronidazole. A standard course of 5 to 7 days should effectively treat $90 \%$ or more of infected individuals. Although the efficacy of 3 days of 2 to $2.4 \mathrm{~g}$ in a single daily dose approaches that of longer regimens, this regimen is not recommended. The drug has not 
received a Food and Drug Administration indication for giardiasis, and these high doses may have increased side effects. Furazolidone is an effective alternative but requires 7 to 10 days of treatment four times a day, which will probably affect compliance. Of the newer therapeutics, albendazole in a 5-day regimen seems most promising, but additional studies are needed. It has the advantage of having broad antiparasitic effect, which may be beneficial in developing-world settings.

In pregnancy, if treatment is required, paromomycin should be tried in the first trimester and paromomycin or metronidazole should be used in the second and third trimesters.

Treatment of all asymptomatic patients calls for careful interpretation of the clinical situation, but they may not always require therapy.

It can be expected that parasites will be cleared from the stool in 3 to 5 days and that symptoms will resolve in 5 to 7 days $(91,100,131,171)$. If the symptoms do not abate, the patient should be evaluated for treatment failure or lactose intolerance. If resistance or relapse has occurred, treatment with a drug of a different class or with a combination of a nitroimidazole and quinacrine for at least 2 weeks should eradicate infection.

\section{ACKNOWLEDGMENT}

We thank Theodore Nash for helpful comments and suggestions.

\section{REFERENCES}

1. Reference deleted.

2. Reference deleted.

3. Abdi, Y. A., L. L. Gustafsson, O. Ericsson, and U. Hellgren. 1995. Handbook of drugs for tropical parasitic infections, 2nd ed. p. 12-16. Taylor \& Francis Ltd., London, United Kingdom.

4. Addiss, D. G., J. P. Davis, J. M. Roberts, and E. E. Mast. 1992. Epidemiology of giardiasis in Wisconsin: increasing incidence of reported cases and unexplained seasonal trend. Am. J. Trop. Med. Hyg. 47:13-19.

5. Addiss, D. G., D. D. Juranek, and H. C. Spencer. 1991. Treatment of children with asymptomatic and nondiarrheal Giardia infection. Pediatr. Infect. Dis. J. 10:843-846.

6. Agarwal, A. K., M. Singh, M. Gupta, R. Saxena, A. Puri, A. K. Verma, R. P. Saxena, C. B. Dubey, and K. C. Saxena. 1994. Management of giardiasis by an immuno-modulatory herbal drug Pippali rasayana. J. Ethnopharmacol. 44:143-146.

7. Aldeen, W. E., K. Carroll, A. Robison, M. Morrison, and D. Hale. 1998. Comparison of nine commercially available enzyme-linked immunosorbent assays for the detection of Giardia lamblia in fecal specimens. J. Clin. Microbiol. 36:1338-1340.

8. Al-Waili, N. S., B. H. Al-Waili, and K. Y. Saloom. 1988. Therapeutic use of mebendazole in giardial infections. Trans. R. Soc. Trop. Med. Hyg. 82:438.

9. Al-Waili, N. S. D., and N. U. Hasan.1992. Mebendazole in giardial infections: a comparative study with metronidazole. J. Infect. Dis. 165:11701171 .

10. American Academy of Pediatrics Committee on Drugs. 1994. The transfer of drugs and other chemicals into human milk. Pediatrics 93:137-150.

11. Andersson, T., J. Forssell, and G. Sterner. 1972. Outbreak of giardiasis: effect of a new antiflagellate drug, tinidazole. Br. Med. J. 2:449-451.

12. Andrews, B. J., and B. Bjorvatin. 1994. Chemotherapy of Entamoeba histolytica: studies in vitro with bacitracin and its zinc salt. Trans. R. Soc. Trop. Med. Hyg. 88:98-100.

13. Andrews, B. J., H. Mylvaganam, and A. Yule. 1994. In vitro sensitivity of Trichomonas vaginalis, Tritrichomonas foetus and Giardia intestinalis to bacitracin and its zinc salt. Trans. R. Soc. Trop. Med. Hyg. 88:704-706.

14. Andrews, B. J., D. Panitescu, G. H. Jipa, A. C. Vasile-Bugarin, R. P. Vasiliu, and J. R. Ronnevig. 1995. Chemotherapy for giardiasis: randomized clinical trial of bacitracin, bacitracin zinc, and a combination of bacitracin zinc with neomycin. Am. J. Trop. Med. Hyg. 52:318-321.

15. Awadalla, H. N., S. H. el-Gowhary, H. A. H. Sadaka, and A. M. Khalifa. 1995. Aminosidine sulphate in experimental giardiasis. J. Egypt. Soc. Parasitol. 25:53-61.

16. Bakshi, J. S., J. M. Ghiara, and A. S. Nanivadeker. 1978. How does tinidazole compare with metronidazole? A summary of reports of Indian trials in amoebiasis and giardiasis. Drugs 15:S31-S42.

17. Reference deleted.
18. Bartlett, A. V., S. J. Englender, B. A. Jarvis, L. Ludwig, J. F. Carlson, and J. P. Topping. 1991. Controlled trial of Giardia lamblia: control strategies in day care centers. Am. J. Public Health 81:1001-1006.

19. Bassily, S., Z. Farid, N. A. el Masry, and E. M. Mikhail. 1987. Treatment of intestinal E. histolytica and $G$. lamblia with metronidazole, tinidazole, and ornidazole: a comparative study. J. Trop. Med. Hyg. 90:9-12.

20. Bassily, S., Z. Farid, J. W. Mikhail, D. C. Kent, and J. S. Lehman. 1970. The treatment of Giardia lamblia infection with mepacrine, metronidazole and furazolidone. J. Trop. Med. Hyg. 73:15-18.

21. Baveja, U. K., V. N. Bhatia, and D. C. Warhurst. 1998. Giardia lamblia: in-vitro sensitivity to some chemotherapeutic agents. J. Commun. Dis. 30: $79-84$.

22. Bean, N. H., J. S. Goulding, C. Lao, and F. J. Angulo. 1996. Surveillance for foodborne-disease outbreaks-United States, 1988-1992. CDC Surveillance Summaries, October 25, 1996. Morb. Mortal. Wkly. Rep. 45(NSS-5): $1-66$.

23. Beard, C. M., K. L. Noller, and W. M. O'Fallon. 1988. Cancer after exposure to metronidazole. Mayo Clin. Proc. 63:147-153.

24. Beard, C. M., K. L. Noller, W. M. O'Fallon, L. T. Kurland, and M. B. Dockerty. 1979. Lack of evidence for cancer due to use of metronidazole. N. Engl. J. Med. 301:519-522.

25. Bell, C. A., M. Cory, T. A. Fairley, J. E. Hall, and R. R. Tidwell. 1991 Structure-activity relationships of pentamidine analogs against Giardia lamblia and correlation of antigiardial activity with DNA-binding affinity. Antimicrob. Agents Chemother. 35:1099-1107.

26. Berget, A., and T. Weber. 1972. Metronidazole and pregnancy. Ugeskr. Laeg. 134:2085-2089.

27. Bingham, A. K., and E. A. Meyer. 1979. Giardia excystation can be induced in vitro in acidic solutions. Nature (London). 277:301-302.

28. Black, R. E., A. C. Dykes, S. P. Sinclair, and J. G. Wells. 1977. Giardiasis in day-care centers: evidence of person-to-person transmission. Pediatrics 60:486-491.

29. Boreham, P. F. L., R. E. Phillips, and R. W. Shepherd. 1988. Altered uptake of metronidazole in vitro by stocks of Giardia intestinalis with different drug sensitivities. Trans. R. Soc. Trop. Med. Hyg. 82:104-106.

30. Boreham, P. F. L., R. E. Phillips, and R. W. Shepherd. 1985. A comparison of the in-vitro activity of some 5-nitroimidazoles and other compounds against Giardia intestinalis. J. Antimicrob. Chemother. 16:589-595.

31. Boreham, P. F. L., R. E. Phillips, and R. W. Shepherd. 1987. Heterogeneity in the responses of clones to Giardia intestinalis to anti-giardial drugs. Trans. R. Soc. Trop. Med. Hyg. 81:406-407.

32. Boreham, P. F. L., R. E. Phillips, and R. W. Shepherd. 1984. The sensitivity of Giardia intestinalis to drugs in vitro. J. Antimicrob. Chemother. 14:449461.

33. Boreham, P. F. L., and J. A. Upcroft. 1991. The activity of azithromycin against stocks of Giardia intestinalis in vitro and in vivo. Trans. R. Soc. Trop. Med. Hyg. 85:620-621.

34. Bost, R. G. 1977. Metronidazole: mammalian mutagenicity, p. 126-131. Proceedings of the International Metronidazole Conference, Montreal, Canada. Excerpta Medica, Amsterdam, The Netherlands.

35. Reference deleted.

36. Briggs, G. G., R. K. Freeman, and S. J. Yaffe. 1990. Metronidazole, p. 430-433. In G. G. Briggs, R. K. Freeman, and S. J. Yaffe (ed.), Drugs in pregnancy and lactation, 3rd ed. The Williams \& Wilkins Co., Baltimore, Md.

37. Brodsky, R. E., H. C. Spencer, and M. G. Schultz. 1974. Giardiasis in American travelers to the Soviet Union. J. Infect. Dis. 130:319-323.

38. Brown, D. M., J. A. Upcroft, and P. Upcroft. 1996. A $\mathrm{H}_{2} \mathrm{O}$-producing NADH oxidase from the protozoan parasite Giardia duodenalis. Eur. J. Biochem. 241:155-161.

39. Bulut, B. U., S. B. Gulnar, and D. Aysev. 1996. Alternative treatment protocols in giardiasis: a pilot study. Scand. J. Infect. Dis. 28:493-495.

40. Buret, A., N. denHollander, P. M. Wallis, D. Befus, and M. E. Olson. 1991. Zoonotic potential of giardiasis in domestic ruminants. J. Infect. Dis. 162: 231-237.

41. Buret, A., D. G. Gall, P. N. Nation, and M. E. Olson. 1990. Intestinal protozoa and epithelial kinetics, structure and function. Parasitol. Today 12:375-380.

42. Burtin, P., A. Taddio, O. Ariburnu, T. R. Einarson, and G. Koren. 1995. Safety of metronidazole in pregnancy: a meta-analysis. Am. J. Obstet. Gynecol. 172:525- 529 .

43. Butcher, P. D., A. M. Cevallos, S. Carnaby, E. M. Alstead, E. T. Swarbrick, and M. J. G. Farthing. 1994. Phenotypic and genotypic variation in Giardia lamblia isolates during chronic infection. Gut 35:51-54.

44. Cacopardo, B., I. Patamia, V. Bonaccorso, O. Di Paola, S. Bonforte, and G. Brancati. 1995. Efficacia sinergica dell'associazione albendazole-metronidazolo nella giardiasi refrattaria a monoterapia con metronidazolo. Clin. Ter. 146:761-767.

45. Calzada, F., C. M. Cerda-Garcia-Rojas, M. Meckes, R. Cedillo-Rivera, R. Bye, and R. Mata. 1999. Geranins A and B, new antiprotozoal A-type proanthocyanidins from Geranium nivem. J. Nat. Prod. 62:705-709.

46. Carnaby, S., P. H. Ketelaris, A. Neem, and M. J. G. Farthing. 1994. Ge- 
notypic heterogeneity within Giardia lamblia isolates demonstrated by M13 DNA fingerprinting. Infect. Immun. 62:1875-1880.

47. Carter, C. H., A. Bayles, and P. E. Thompson. 1962. Effects of paromomycin sulfate in man against Entamoeba histolytica and other intestinal protozoa. Am. J. Trop. Med. Hyg. 11:448-451.

48. Chávez, B., L. González-Mariscal, R. Cedillo-Rivera, and A. MartínezPalomo. 1995. Giardia lamblia: in vitro cytopathic effect of human isolates. Exp. Parasitol. 80:133-138.

49. Cimerman, B., H. Boruchovski, F. M. Cury, L. M. Bichued, and A. Ieri. 1989. A comparative study of secnidazole and metronidazole in the treatment of giardiasis, p. 28-34. In N. Katz and A. T. Willis (ed.), Secnidazole: a new approach in 5-nitroimidazole therapy. Proceedings from the 16th International Congress of Chemotherapy. Excerpta Medica, Amsterdam, The Netherlands.

50. Clark, D. P. 1999. New insights into human cryptosporidiosis. Clin. Microbiol. Rev. 12:554-563.

51. Clark, J. T., and D. V. Holberton. 1988. Triton-labile antigens in flagella isolated from Giardia lamblia. Parasitol. Res.74:415-423.

52. Craft, J. C., T. Murphy, and J. D. Nelson. 1981. Furazolidone and quinacrine. Comparative study of therapy for giardiasis in children. Am. J. Dis. Child. 135:164-166.

53. Craun, G. F. 1986. Waterborne giardiasis in the United States 1965-1984. Lancet ii:513-514.

54. Craun, G. F. 1996. Waterborne outbreaks of giardiasis: current status, p. 243-261. In S. L. Erlandsen and E. A. Meyer (ed.), Giardia and giardiasis: biology, pathogenesis, and epidemiology. Plenum Press, New York, N.Y.

55. Crouch, A. A., W. K. Seow, and Y. H. Thong. 1986. Effect of twenty-three chemotherapeutic agents on the adherence and growth of Giardia lamblia in vitro. Trans. R. Soc. Trop. Med. Hyg. 80:893-896.

56. Crouch, A. A., W. K. Seow, L. M. Whitman, and Y. H. Thong. 1990. Sensitivity in vitro of Giardia intestinalis to dyadic combinations of azithromycin, doxycycline, mefloquine, tinidazole and furazolidone. Trans. R. Soc. Trop. Med. Hyg. 84:246-248.

57. Darbon, A., A. Portal, L. Girier, J. Pantin, and C. Leclaire. 1962. Traitement de la giardiase (lambliase) par le métronidazole. Presse Med. 70:1516.

58. Davidson, R. A. 1984. Issues in clinical parasitology: the treatment of giardiasis. Am. J. Gastroenterol. 79:256-261.

59. deRegnier, D. P., L. Cole, D. G. Schupp, and S. L. Erlandsen. 1989. Viability of Giardia cysts suspended in lake, river, and tap water. Appl. Environ. Microbiol. 55:1223-1229.

60. Reference deleted.

61. Djamiatun, K., and G. M. Faubert. 1998. Exogenous cytokines released by spleen and Peyer's patch cells removed from mice infected with Giardia muris. Parasite Immunol. 20:27-36.

62. Dobell, C. 1920. The discovery of the intestinal protozoa of man. Proc. R. Soc. Med. 13:1-15.

63. Dobón, J. F., A. E. Cedrato, and N. Martino de Colom. 11 July 1963. El uso de la paromomicina en amebiasis y giardiasis intestinalis, p. 1012, El Día Médico, Buenos Aires, Argentina.

64. Doumbo, O., J. F. Rossignol, E. Pichard, H. A. Traore, M. Dembele, M. Diakite, F. Traore, and D. A. Diallo. 1997. Nitazoxanide in the treatment of cryptosporidial diarrhea and other intestinal parasitic infections associated with acquired immunodeficiency syndrome in tropical Africa. Am. J. Trop. Med. Hyg. 56:637- 639.

65. Duncombe, V. M., T. D. Bolin, A. E. Davis, and R. L. Crouch. 1978. Histopathology in giardiasis: a correlation with diarrhea. Aust. N. Z. J. Med. 8:392-396.

66. DuPont, H. L., and E. G. Capsuto. 1996. Persistent diarrhea in travelers. Clin. Infect. Dis. 22:124-128.

67. Durel, P., V. Roiron, H. Siboulet, and L. J. Borel. 1960. Systemic treatment of human trichomoniasis with a derivative of nitroimidazole. Br. J. Vener. Dis. 36:21-26.

68. Dutta, A. K., M. A. Phadke, A. C. Bagade, V. Joshi, A. Gazder, T. K. Biswas, H. H. Gill, and S. C. Jagota. 1994. A randomised multicentre study to compare the safety and efficacy of albendazole and metronidazole in the treatment of giardiasis in children. Indian J. Pediatr. 61:689-693.

69. Edlind, T. D. 1989. Susceptibility of Giardia lamblia to aminoglycoside protein synthesis inhibitors: correlation with rRNA structure. Antimicrob. Agents Chemother. 33:484-488.

70. Edlind, T. D. 1989. Tetracyclines as antiparasitic agents: lipophilic derivatives are highly active against Giardia lamblia in vitro. Antimicrob. Agents Chemother. 33:2144-2145.

71. Edlind, T. D., T. L. Hang, and P. R. Chakraborty. 1990. Activity of the anthelminthic benzimidazoles against Giardia intestinalis in vitro. J. Infect. Dis. 162:1408-1411.

72. Edwards, D. I. 1993. Nitroimidazole drugs-action and resistance mechanisms. I. Mechanisms of action. J. Antimicrob. Chemother. 31:9-20.

73. Elliott, A. M., B. D. Klaus, D. S. North, and H. P. Martin. 1998. Furazolidone-induced mood disorder during the treatment of refractory giardiasis in a patient with AIDS. Clin. Infect. Dis. 26:1015.

74. Erlandsen, S., L. A. Sherlock, M. Januschka, D. G. Schupp, F. W. Schaefer
III, W. Jakubowski, and W. J. Bemrick. 1988. Cross-species transmission of Giardia spp.: inoculation of beavers and muskrats with cysts of human, beaver, mouse, and muskrat origin. Appl. Environ. Microbiol. 54:27772785.

75. Erlandsen, S. L., P. T. Macechko, H. van Keulen, and E. L. Jarroll. 1996. Formation of the Giardia cyst wall: studies on extracellular assembly using immunogold labeling and high resolution field emission SEM. J. Eukaryot. Microbiol. 43:416-429.

76. Erlich, J. H., R. F. Anders, I. C. Roberts-Thomson, J. W. Schrader, and G. F. Mitchell. 1983. An examination of differences in serum antibody specificities and hypersensitivity reactions as contributing factors to chronic infection with the intestinal protozoan parasite, Giardia muris, in mice. Aust. J. Exp. Biol. Med. Sci. 61:599-615.

77. Ey, P. L., T. Bruderer, C. Wehrli, and P. Kohler. 1996. Comparison of genetic groups determined by molecular and immunological analyses of Giardia isolated from animals and humans in Switzerland and Australia. Parasitol. Res. 82:52-60

78. Falagas, M. E., A. M. Walker, H. Jick, R. Ruthazer, J. Griffith, and D. R. Snydman. 1998. Late incidence of cancer after metronidazole use: a matched metronidazole user/nonuser study. Clin. Infect. Dis. 26:384-388.

79. Farbey, M. D., J. A. Reynoldson, and R. C. Thompson. 1995. In vitro drug susceptibility of 29 isolates of Giardia intestinalis from humans as assessed by an adhesion assay. Int. J. Parasitol. 25:593-599.

80. Reference deleted.

81. Farthing, M. J. G. 1992. Giardia comes of age: progress in epidemiology, immunology and chemotherapy. J. Antimicrob. Chemother. 30:563-566.

82. Farthing, M. J. G. 1996. Giardiasis. Gastroenterol. Clin. North Am. 25: 493-515.

83. Farthing, M. J. G. 1997. The molecular pathogenesis of giardiasis. J. Pediatr. Gastroenterol. Nutr. 24:79-88.

84. Farthing, M. J. G., and P. M. G. Inge. 1986. Antigiardial activity of the bile salt-like solution antibiotic sodium fusidate. J. Antimicrob. Chemother. 17:165-171.

85. Farthing, M. J. G., P. M. G. Inge, and R. M. Pearson. 1987. Effect of D-propranolol on growth and motility of flagellate protozoa. J. Antimicrob. Chemother. 20:519-522.

86. Farthing, M. J. G., L. Mata, J. J. Urrutia, and R. A. Kronmal. 1986. Natural history of Giardia infection of infants and children in rural Guatemala and its impact on physical growth. Am. J. Clin. Nutr. 43:395-405.

87. Faubert, G. 2000. Immune response to Giardia duodenalis. Clin. Microbiol. Rev. 13:35-54.

88. Reference deleted.

89. Garcia, L. S., and R. Y. Shimizu. 2000. Detection of Giardia lamblia and Cryptosporidium parvum antigens in human fecal specimens using the ColorPac combination rapid solid-phase qualitative immunochromatographic assay. J. Clin. Microbiol. 38:1267-1268.

90. Garcia, L. S., and R. Y. Shimizu. 1997. Evaluation of nine immunoassay kits (enzyme immunoassay and direct fluorescence) for detection of Giardia lamblia and Cryptosporidium parvum in human fecal specimens. J. Clin. Microbiol. 35:1526-1529.

91. Garg, B. K. 1972. Furazolidone and metronidazole in the treatment of giardiasis. Indian J. Pediatr. 39:264-266.

92. Gascón, J., R. Abós, M. E. Valls, and M. Corachán. 1990. Mebendazole and metronidazole in giardial infections. Trans. R. Soc. Trop. Med. Hyg. 84:694.

93. Gazder, A. J., and M. Banerjee. 1978. Single dose therapy of giardiasis with tinidazole and metronidazole. Drugs 15:S30-S32.

94. Gillin, F. D., and L. S. Diamond. 1981. Inhibition of clonal growth of Giardia lamblia and Entamoeba histolytica by metronidazole, quinacrine and other antimicrobial agents. J. Antimicrob. Chemother. 8:305-316.

95. Gillis, J. C., and L. R. Wiseman. 1996. Secnidazole. A review of its antimicrobial activity, pharmacokinetic properties and therapeutic use in the management of protozoal infections and bacterial vaginosis. Drugs 51:621638 .

96. Gilman, R. H., E. Miranda, G. S. Marquis, M. Vestegui, and H. Martinez. 1988. Rapid reinfection by Giardia lamblia after treatment in a hyperendemic Third World community. Lancet i:343-345.

97. Goka, A. K. J., D. D. K. Rolston, V. I. Mathan, and M. J. G. Farthing. 1990 The relative merits of faecal and duodenal juice microscopy in the diagnosis of giardiasis. Trans. R. Soc. Trop. Med. Hyg. 84:66-67.

98. Goldman, P. 1980. Metronidazole. N. Engl. J. Med. 303:1212-1218.

99. Goodgame, R. W. 1996. Understanding intestinal spore-forming protozoa: cryptosporidia, microsporidia, isospora, and cyclospora. Ann. Intern. Med. 124:429-441.

100. Gorbea Robles, M. C., J. G. Eternod, F. G. Valázquez, et al. 1989. Estudio comparativo en amebiasis y giardiasis intestinal del lactante y pre-escolar: eficacia y tolerancia del secnidazol vs metronidazol y etofamida. Investig. Med. Int. 16:79-82.

101. Gordts, B., W. Hemelhof, C. Asselman, and J. P. Butzler. 1985. In vitro susceptibilities of 25 Giardia lamblia isolates of human origin to six commonly used antiprotozoal agents. Antimicrob. Agents Chemother. 28:378380.

102. Reference deleted. 
103. Gupta, M. C., and J. J. Urrutia. 1982. Effect of periodic antiascaris and antigiardia treatment on nutritional status of preschool children. Am. J. Clin. Nutr. 36:79-86.

104. Hall, A., and Q. Nahar. 1993. Albendazole as a treatment for infections with Giardia duodenalis in children in Bangladesh. Trans. R. Soc. Trop. Med. Hyg. 87:84-86.

105. Hartman, H. R., and F. A. Kyser. 1941. Giardiasis and its treatment. JAMA 116:2835-2839.

106. Hartong, W. A., W. K. Gourley, and C. Arvanitakis. 1979. Giardiasis: clinical spectrum and functional-structural abnormalities of the small intestinal mucosa. Gastroenterology 77:61-69.

107. Heinonen, O. P., D. Slone, and S. Shapiro. 1977. Birth defects and drugs in pregnancy, p. 296-302. Publishing Sciences Group, Littleton, Mass.

108. Herzog, D., B. Hammer, J. Neuweiler, and E. Werder. 1998. Chronische Giardiasis mit intestinalem Kleinwuchs and Pubertas tarda bei Immunoglobulinmangelsyndrom: vollstandiges Aufholwachstum nach Therapie. Schweiz. Med. Wochenschr. 128:623-628.

109. Hetsko, M. L., J. M. McCaffery, S. G. Svard, T. C. Meng, X. Que, and F. D. Gillin. 1998. Cellular and transcriptional changes during excystation of Giardia lamblia in vitro. Exp. Parasitol. 88:172-183.

110. Heyworth, M. F. 1992. Immunology of Giardia and Cryptosporidium infections. J. Infect. Dis. 166:465-472.

111. Hiatt, R. A., E. K. Markell, and E. Ng. 1995. How many stool examinations are necessary to detect pathogenic intestinal protozoa? Am. J. Trop. Med. Hyg. 53:36-39.

112. Hill, D. R. Giardia lamblia. In S. H. Gillespie and R. D. Pearson (ed.), Principles and practice of clinical parasitology, in press. John Wiley \& Sons, Ltd., Chichester, England.

113. Hill, D. R. 1993. Giardiasis: Issues in management and treatment. Infect. Dis. Clin. North Am. 7:503-525.

114. Hill, D. R., J. J. Burge, and R. D. Pearson. 1984. Susceptibility of Giardia lamblia trophozoites to the lethal effect of human serum. J. Immunol. 132:2046-2052.

115. Hill, D. R., and T. E. Nash. 1999. Intestinal flagellate and ciliate infections, p. 703-720. In R. L. Guerrant, D. H. Walker, and P. F. Weller (ed.), Tropical infectious diseases. Principles, pathogens, \& practice, vol. 1. Churchill Livingstone, Philadelphia, Pa.

116. Hill, D. R., R. Pohl, and R. D. Pearson. 1986. Giardia lamblia: a culture method for determining parasite viability. Am. J. Trop. Med. Hyg. 35:11291133.

117. Inge, P. M. G., and M. J. G. Farthing. 1987. A radiometric assay for antigiardial drugs. Trans. R. Soc. Trop. Med. Hyg. 81:345-347.

118. Isaac-Renton, J., J. Blatherwick, W. R. Bowie, M. Fyfe, M. Khan, A. Li, A. King, M. McLean, L. Meed, W. Moorehead, C. S. Ong, and W. Robertson. 1999. Epidemic and endemic seroprevalence of antibodies to Cryptosporidium and Giardia in residents of three communities with different drinking water supplies. Am. J. Trop. Med. Hyg. 60:578-583.

119. Isaac-Renton, J. L., L. F. Lewis, C. S. Ong, and M. F. Nulsen. 1994. A second community outbreak of waterborne giardiasis in Canada and serological investigation of patients. Trans. R. Soc. Trop. Med. Hyg. 88:395399.

120. Isaac-Renton, J. L., H. Shahriari, and W. R. Bowie. 1992. Comparison of an in vitro method and an in vivo method of Giardia excystation. Appl. Environ. Microbiol. 58:1530-1533.

121. Ish-Horowicz, M., S. H. Korman, M. Shapiro, U. Har-Even, I. Tamir, N. Strauss, and R. J. Deckelbaum. 1989. Asymptomatic giardiasis in children. Pediatr. Infect. Dis. J. 8:773-779.

122. Jarroll, E. L., A. K. Bingham, and E. A. Meyer. 1981. Effect of chlorine on Giardia lamblia cyst viability. Appl. Environ. Microbiol. 41:483-487.

123. Jephcott, A. E., N. T. Begg, and I. A. Baker. 1986. Outbreak of giardiasis associated with mains water in the United Kingdom. Lancet i:730-732.

124. Johns, T., G. M. Faubert, J. O. Kokwaro, R. L. A. Mahunnah, and E. K. Kimanani. 1995. Anti-giardial activity of gastrointestinal remedies of the Luo of east Africa. J. Ethnopharmacol. 46:17-23.

125. Jokipii, A. M. M., M. Hemilä, and L. Jokipii. 1985. Prospective study of acquisition of cryptosporidium, Giardia lamblia, and gastrointestinal illness. Lancet ii:487-489.

126. Jokipii, A. M. M., and L. Jokipii. 1978. Comparative evaluation of two dosages of tinidazole in the treatment of giardiasis. Am. J. Trop. Med. Hyg. 27:758-761.

127. Jokipii, L., and A. M. M. Jokipii. 1978. Comparison of four dosage schedules in the treatment of giardiasis with metronidazole. Infection. 6:92-94.

128. Jokipii, L., and A. M. M. Jokipii. 1974. Giardiasis in travelers: a prospective study. J. Infect. Dis. 130:295-299.

129. Jokipii, L., and A. M. M. Jokipii. 1980. In vitro susceptibility of Giardia lamblia to metronidazole and tinidazole. J. Infect. Dis. 141:317-325.

130. Jokipii, L., and A. M. M. Jokipii. 1979. Single-dose metronidazole and tinidazole as therapy for giardiasis: success rates, side effects, and drug absorption and elimination. J. Infect. Dis. 140:984-988.

131. Jokipii, L., and A. M. M. Jokipii. 1982. Treatment of giardiasis: comparative evaluation of ornidazole and tinidazole as a single oral dose. Gastroenterology 83:399-404.
132. Kalyci, A. G., F. Cetinbkaya, M. Gunaydin, and N. Gurses. 1995. Comparison of mebendazole with metronidazole and furazolidone in the treatment of giardiasis in children. Ann. Saudi Med. 15:655-656.

133. Kang, E. W., K. Clinch, R. H. Furneaux, J. E. Harvey, P. J. Schofield, and A. M. Gero. 1998. A novel and simple colorimetric method for screening Giardia intestinalis and anti-giardial activity in vitro. Parasitology 117:229234

134. Kaucner, C., and T. Stinear. 1998. Sensitive and rapid detection of viable Giardia cysts and Cryptosporidium parvum oocysts in large-volume water samples with wound fiberglass cartridge filters and reverse transcriptionPCR. Appl. Environ. Microbiol. 64:1743-1749.

135. Kavousi, S. 1979. Giardiasis in infancy and childhood: a prospective study of 160 cases with comparison of quinacrine (Atabrine $\left.{ }^{\circledR}\right)$ and metronidazole (Flagyl $\left.{ }^{\circledR}\right)$. Am. J. Trop. Med. Hyg. 28:19-23.

136. Kettis, A. A., and L. G. Magnius. 1973. Giardia lamblia infection in a group of students after a visit to Leningrad in March 1970. Scand. J. Infect. Dis. 5:289-292.

137. Kollaritsch, H., E. Jeschko, and G. Wiederman. 1993. Albendazole is highly effective against cutaneous larva migrans but not against Giardia infection: results of an open pilot trial in travellers returning from the tropics. Trans. R. Soc. Trop. Med. Hyg. 87:689.

138. Korman, S. H., E. Hais, and D. T. Spira. 1990. Routine in vitro cultivation of Giardia lamblia by using the string test. J. Clin. Microbiol. 28:368-369.

139. Kramer, M. H., B. L. Herwaldt, G. F. Craun, R. L. Calderon, and D. D. Juranek. 1996. Surveillance for waterborne-disease outbreaks-United States, 1993-1994. CDC Surveillance Summaries, April 12, 1996. Morb. Mortal. Weekly Rep. 45(SS-1):1-30.

140. Kreutner, A. K., V. E. Del Bene, and M. S. Amstey. 1981. Giardiasis in pregnancy. Am. J. Obstet. Gynecol. 140:895-901.

141. Kucers, A., S. M. Crowe, M. L. Grayson, and J. F. Hoy. 1997. Bacitracin and gramicidin, p. 542-543. In A. Kucers, S. M. Crowe, M. L. Grayson, and J. F. Hoy (ed.), The use of antibiotics. A clinical review of antibacterial, antifungal, and antiviral drugs, 5th ed. Butterworth-Heinemann, Oxford, United Kingdom.

142. Kucers, A., S. M. Crowe, M. L. Grayson, and J. F. Hoy. 1997. Neomycin, framycetin and paromomycin, p. 533-541. In A. Kucers, S. M. Crowe, M. L. Grayson, and J. F. Hoy (ed.), The use of antibiotics. A clinical review of antibacterial, antifungal, and antiviral Drugs, 5th ed. Butterworth-Heinemann, Oxford, United Kingdom.

143. Kucers, A., S. M. Crowe, M. L. Grayson, and J. F. Hoy. 1997. Nitrofurans: nitrofurozone, furazolidone and nitrofurantoin, p. 922-923. In A. Kucers, S. M. Crowe, M. L. Grayson, and J. F. Hoy (ed.), The use of antibiotics. A clinical review of antibacterial, antifungal, and antiviral drugs, 5th ed. Butterworth-Heinemann, Oxford, United Kingdom.

144. Kusumi, R. K., J. F. Plouffe, R. H. Wyatt, and R. J. Fass. 1980. Central nervous system toxicity associated with metronidazole therapy. Ann. Intern. Med. 93:59-60.

145. Kuzmicki, R., and J. Jeske. 1994. Observations of the efficacy of ornidazole (Tiberal La Roche) in treatment of giardiasis. Wiad. Parazytol. 40:65-68.

146. Kyrönseppä, H., and T. Pettersson. 1981. Treatment of giardiasis: relative efficacy of metronidazole as compared with tinidazole. Scand. J. Infect. Dis. 13:311-312.

147. Lau, A. H., N. P. Lam, S. C. Piscitelli, L. Wilkes, and L. H. Danzinger. 1992. Clinical pharmacokinetics of metronidazole and other nitroimidazole antiinfectives. Clin. Pharmacokinet. 23:328-364.

148. Laughon, B. E., D. A. Druckman, A. Vernon, T. C. Quinn, B. F. Polk, J. F. Modlin, R. H. Yolken, and J. G. Bartlett. 1988. Prevalence of enteric pathogens in homosexual men with and without acquired immunodeficiency syndrome. Gastroenterology 94:984-993.

149. Lengerich, E. J., D. G. Addiss, and D. D. Juranek. 1994. Severe giardiasis in the United States. Clin. Infect. Dis. 18:760-763.

150. Lerman, S. J., and R. A. Walker. 1982. Treatment of giardiasis. Literature review and recommendations. Clin. Pediatr. 21:409-414.

151. Levi, G. C., C. A. de Avila, and V. A. Neto. 1977. Efficacy of various drugs for treatment of giardiasis. A comparative study. Am. J. Trop. Med. Hyg. 26:564-565.

152. Levine, W. C., J. F. Smart, D. L. Archer, N. H. Bean, and R. V. Tauxe. 1991 Foodborne disease outbreaks in nursing homes, 1975 through 1987. JAMA 266:2105-2109.

153. Lindmark, D. G., and M. Muller. 1976. Antitrichomonad action, mutagenicity, and reduction of metronidazole and other nitroimidazoles. Antimicrob. Agents Chemother. 10:476-482.

154. Lindquist, H. D. 1996. Induction of albendazole resistance in Giardia lamblia. Microb. Drug Resist. 2:433-434.

155. Liu, L. X., and P. F. Weller. 1996. Antiparasitic drugs. N. Engl. J. Med. 334:1178-1184.

156. Lujan, H. D., M. R. Mowatt, and T. E. Nash. 1997. Mechanisms of Giardia lamblia differentiation into cysts. Microbiol. Mol. Biol. Rev. 61:294-304.

157. MacDonald, T. T., and J. Spencer. 1988. Evidence that activated mucosal T cells play a role in the pathogenesis of enteropathy in human small intestine. J. Exp. Med. 167:1341-1349.

158. Mahbubani, M. H., F. W. I. Schaefer, D. D. Jones, and A. K. Bej. 1998. 
Detection of Giardia in environmental waters by immuno-PCR amplification methods. Curr. Microbiol. 36:107-113.

159. Mahmud, M. A., C. Chappell, M. M. Hossain, M. Habib, and H. L. DuPont. 1995. Risk factors for development of first symptomatic Giardia infection among infants of a birth cohort in rural Egypt. Am. J. Trop. Med. Hyg. 53:84-88.

160. Majewska, A. C., W. Kasprzak, J. F. De Jonckheere, and E. Kaczmarek. 1991. Heterogeneity in the sensitivity of stocks and clones of Giardia to metronidazole and ornidazole. Trans. R. Soc. Trop. Med. Hyg. 85:67-69.

161. Mank, T. G., J. O. Zaat, A. M. Deelder, J. T. van Eijk, and A. M. Polderman. 1997. Sensitivity of microscopy versus enzyme immunoassay in the laboratory diagnosis of giardiasis. Eur. J. Clin. Microbiol. Infect. Dis. 16: 615-619.

162. Markell, E. K., R. F. Havens, R. A. Kuritsubo, and J. Wingerd. 1984. Intestinal protozoa in homosexual men of the San Francisco Bay area: prevalence and correlates of infection. Am. J. Trop. Med. Hyg. 33:239-245.

163. Mata, L. J. 1978. The children of Santa María Cauqué: a prospective field study of health and growth. MIT Press, Cambridge, Mass.

164. McIntyre, P., P. F. L. Boreham, R. E. Phillips, and R. W. Shepard. 1986. Chemotherapy in giardiasis: clinical responses and in vitro drug sensitivity of human isolates in axenic culture. J. Pediatr. 108:1005-1010.

164a.Medical Economics Company, Inc. 1999. Flagyl, p. 2961-2963. In Physicians' desk reference, 53rd ed. Medical Economics Co., Inc., Montvale, N.J.

164b.Medical Economics Company, Inc. 1999. Furoxone, p. 2627. In Physicians' desk reference, 53rd ed. Medical Econimics Co., Inc., Montvale, N.J.

165. Meingasser, J. G., and P. G. Heyworth. 1981. Intestinal and urogenital flagellates. Antibiotics Chemother. 30:163-202.

166. Meloni, B. P., R. C. A. Thompson, J. A. Reynoldson, and P. Seville. 1990. Albendazole: a more effective antigiardial agent in vitro than metronidazole or tinidazole. Trans. R. Soc. Trop. Med. Hyg. 84:375-379.

167. Meyer, E. A., and S. Radulescu. 1979. Giardia and giardiasis. Adv. Parasitol. 17:1-47.

168. Meyers, J. D., H. A. Kuharic, and K. K. Holmes. 1977. Giardia lamblia infection in homosexual men. Br. J. Vener. Dis. 53:54-55.

169. Mintz, E. D., M. Hudson-Wragg, P. Mshar, M. L. Cartter, and J. L. Hadler. 1993. Foodborne giardiasis in a corporate office setting. J. Infect. Dis. 167:250-253.

170. Miotti, P. G., R. H. Gilman, M. Santosham, R. W. Ryder, and R. H. Yolken. 1986. Age-related rate of seropositivity of antibody to Giardia lamblia in four diverse populations. J. Clin. Microbiol. 24:972-975.

171. Misra, P. K., A. Kumar, V. Agarwal, and S. C. Jagota. 1995. A comparative trial of albendazole versus metronidazole in children with giardiasis. Indian Pediatr. 32:779-782.

172. Miyares, C., I. Hollands, C. Castaneda, T. Gonzalez, T. Fragaso, R. Curras, and C. Soria. 1988. Ensayo terapeutica con un preparado a base de propoleo "propolisina" en la giardiasis del humano. Acta Gastroenterol. Latinoam. 18:195-201.

173. Monis, P. T., G. Mayrhofer, R. H. Andrews, W. L. Homan, L. Limper, and P. L. Ey. 1996. Molecular genetic analysis of Giardia intestinalis isolates at the glutamate dehydrogenase locus. Parasitology 112:1-12.

174. Moore, G. T., W. M. Cross, D. McGuire, C. S. Mollohan, N. N. Gleason, G. R. Healy, and L. H. Newton. 1969. Epidemic giardiasis at a ski resort. N. Engl. J. Med. 281:402-407.

175. Morgan, U. M., J. A. Reynoldson, and R. C. Thompson. 1993. Activities of several benzimidazoles and tubulin inhibitors against Giardia spp. in vitro. Antimicrob. Agents Chemother. 37:328-331.

176. Morrow, A. L., R. R. Reves, M. S. West, M. L. Guerrero, G. M. RuizPalacios, and L. K. Pickering. 1992. Protection against infection with $\mathrm{Gi}$ ardia lamblia by breast feeding in a cohort of Mexican infants. J. Pediatr. 121:363-370.

177. Muller, M. 1983. Mode of action of metronidazole on anaerobic bacteria and protozoa. Surgery $\mathbf{9 3 : 1 6 5 - 1 7 1 .}$

178. Murphy, T. V., and J. D. Nelson. 1983. Five vs. ten days' therapy with furazolidone for giardiasis. Am. J. Dis. Child. 137:267-270.

179. Namgung, R., J. S. Ryu, K. T. Lee, and C. T. Soh. 1985. The effect of metronidazole and quinacrine on the morphology and the excystation of Giardia lamblia. Yonsei Rep. Trop. Med. 16:28-44.

180. Nash, T., and W. G. Rice. 1998. Efficacies of zinc-finger-active drugs against Giardia lamblia. Antimicrob. Agents Chemother. 42:1488-1492.

181. Nash, T. E. 1997. Antigenic variation in Giardia lamblia and the host's immune response. Philos. Trans. R. Soc. London Ser. B. 352:1369-1375.

182. Nash, T. E., D. A. Herrington, G. A. Losonsky, and M. M. Levine. 1987. Experimental human infections with Giardia lamblia. J. Infect. Dis. 156: 974-984

182a.Nash, T. E., C. A. Ohl, E. Thomas, G. Subramanian, P. Keiser, and T. Moore. Treatment of refractory giardiasis. Clin. Infect. Dis., in press.

183. Nayak, N., N. K. Ganguly, B. N. S. Walia, V. Wahi, S. S. Kanwar, and R. C. Mahajan. 1987. Specific secretory IgA in the milk of Giardia lambliainfected and uninfected women. J. Infect. Dis. 155:724-727.

184. Notis, W. M. 1972. Giardiasis and vitamin B12 malabsorption. Gastroenterology 63:1085.

185. Oberhuber, G., N. Kastner, and M. Stolte. 1997. Giardiasis: a histologic analysis of 567 cases. Scand. J. Infect. Dis. 32:48-51.

186. Oren, B., E. Schgurensky, M. Ephros, I. Tamir, and R. Raz. 1991. Singledose ornidazole versus seven-day metronidazole therapy of giardiasis in Kibbutzim children in Israel. Eur. J. Clin. Microbiol. Infect. Dis. 10:963965.

187. Osterholm, M. T., J. C. Forfang, T. L. Ristinen, A. G. Dean, J. W. Washburn, J. R. Godes, R. A. Rude, and J. G. McCullough. 1981. An outbreak of foodborne giardiasis. N. Engl. J. Med. 304:24-28.

188. Reference deleted.

189. Paget, T. A., E. L. Jarroll, P. Manning, D. G. Lindmark, and D. Lloyd. 1989. Respiration in the cysts and trophozoites of Giardia muris. J. Gen. Microbiol. 135:145-154

190. Paintlia, A. S., S. Descoteaux, B. Spencer, A. Chakraborti, N. K. Ganguly, R. C. Mahajan, and J. Samuelson. 1998. Giardia lamblia groups A and B among young adults in India. Clin. Infect. Dis. 26:190-191.

191. Palomino, H., C. Pérez, R. Donckaster, J. Sapunar, M. Gabor, A. Atías, V. Parodi, and L. Narbona. 1970. Ensayo terapéutico con cinco medicamentos en lambliasis. Bol. Chil. Parasitol. 25:52-56.

192. Pearce, D. A., J. A. Reynoldson, and R. C. Thompson. 1996. A comparison of two methods for assessing drug sensitivity in Giardia duodenalis. Appl. Parasitol. 37:111-116.

193. Pengsaa, K., C. Sirivichayakul, C. Pojjaroen-anant, S. Nimnual, and P. Wisetsing. 1999. Albendazole treatment of Giardia intestinalis infections in school children. S. Asian J. Trop. Med. Public Health 30:78-83.

194. Reference deleted.

195. Pickering, L. K., W. E. Woodward, H. L. DuPont, and P. Sullivan. 1984. Occurrence of Giardia lamblia in children in day care centers. J. Pediatr. 104:522-526.

196. Polis, M. A., C. U. Tuazon, D. W. Alling, and E. Talamis. 1986. Transmission of Giardia lamblia from a day care center to the community. Am. J. Public Health 76:1142-1144.

197. Popovic, O. S., and V. Milovic. 1990. Propranolol and metronidazole for the treatment of metronidazole-resistant giardiasis. J. Clin. Gastroenterol. 12: 604-605.

198. Pungpak, S., V. Singhasivanon, D. Bunnag, B. Radomyos, P. Nibaddhasopon, and K. T. Harinasuta. 1996. Albendazole as a treatment for Giardia infection. Ann. Trop. Med. Parasitol. 90:563-565.

199. Quick, R., K. Paugh, D. Addiss, J. Kobayashi, and R. Baron. 1992. Restaurant-associated outbreak of giardiasis. J. Infect. Dis. 166:673-676.

200. Quinn, T. C., W. E. Stamm, S. E. Goodell, E. Mkrtichian, J. Benedetti, L. Corey, M. D. Schuffler, and K. K. Holmes. 1983. The polymicrobial origin of intestinal infections in homosexual men. N. Engl. J. Med. 309:576-582.

201. Quiros-Buelna, E. 1989. Furazolidone and metronidazole for treatment of giardiasis in children. Scand. J. Gastroenterol. 169:S65-S69.

202. Reference deleted.

203. Rauch, A. M., V. M. T. Rory, A. V. Bartlett, and L. K. Pickering. 1990. Longitudinal study of Giardia lamblia infection in a day care center population. Pediatr. Infect. Dis. J. 9:186-189.

204. Reiner, D. S., C. S. Wang, and F. D. Gillin. 1986. Human milk kills Giardia lamblia by generating toxic lipolytic products. J. Infect. Dis. 154:825-832.

205. Reinthaler, F. F., G. Feierl, D. Stunzner, and E. Marth. 1998. Diarrhea in returning Austrian tourists: epidemiology, etiology, and cost-analysis. J. Travel Med. 5:65-72.

206. Rendtorff, R. C. 1954 . The experimental transmission of human intestinal protozoan parasites. II. Giardia lamblia cysts given in capsules. Am. J. Hyg. 59:209-220.

207. Reynoldson, J. A., J. M. Behnke, M. Gracey, R. J. Horton, R. Spargo, R. M. Hopkins, C. C. Constantine, F. Gilbert, C. Stead, R. P. Hobbs, and R. C. Thompson. 1998. Efficacy of albendazole against Giardia and hookworm in a remote Aboriginal community in the north of Western Australia. Acta Trop. 71:27-44.

208. Reynoldson, J. A., R. C. A. Thompson, and R. J. Horton. 1992. Albendazole as a future antigiardial agent. Parasitol. Today 8:412-414.

209. Reynoldson, J. A., R. C. A. Thompson, and B. P. Meloni. 1991. The mode of action of benzimidazoles against Giardia and their chemotherapeutic potential against Giardia and other parasitic protozoa, p. 587-593. In G. H. Coombs and M. J. North (ed.), Biochemical protozoology. Taylor \& Francis Ltd., London, United Kingdom.

210. Rice, E. W., and F. W. Schaefer. 1981. Improved in vitro excystation procedure for Giardia lamblia cysts. J. Clin. Microbiol. 14:709-710.

211. Rodriguez-Garcia, R., L. M. Rodriguez-Guzman, and A. H. Cruz del Castillo. 1999. Eficacia y seguridad de mebendazol contra nitazoxanida en el tratamiento de Giardia lamblia en niños. Rev. Gastroenterol. Mex. 64: $122-126$.

212. Roe, F. J. C. 1985. Safety of nitroimidazoles. Scand. J. Infect. Dis. 46:72-81.

213. Romero Cabello, R., L. R. Guerrero, M. R. Muñóz García, and A. Geyne Cruz. 1997. Nitazoxanide for the treatment of intestinal protozoan and helminthic infections in Mexico. Trans. R. Soc. Trop. Med. Hyg. 91:701703.

214. Romero-Cabello, R., L. Robert, R. Muñoz-Garcia, and J. Tanaka. 1995. Estudio aleatorio para comparar seguridad y eficacia de albendazol y met- 
ronidazol en el tratamiento de giardiasis en niños. Rev. Latinoam. Microbiol. 37:315-323.

215. Rosa, F. W., C. Baum, and M. Shaw. 1987. Pregnancy outcomes after first-trimester vaginitis drug therapy. Obstet. Gynecol. 69:751-755.

216. Rosen, F. S., M. D. Cooper, and R. J. P. Wedgwood. 1995. The primary immunodeficiencies. N. Engl. J. Med. 333:431-440.

217. Rossignol, J. F., H. Maisonneuve, and Y. W. Cho. 1984. Nitroimidazoles in the treatment of trichomoniasis, giardiasis, and amebiasis. Int. J. Clin. Pharmacol. Ther. Toxicol. 22:63-72.

218. Rotblatt, M. D. 1983. Giardiasis and amebiasis in pregnancy. Drug Intell. Clin. Pharm. 17:187-188.

219. Rousham, E. K. 1994. An increase in Giardia duodenalis infection among children receiving periodic anthelminthic treatment in Bangladesh. J. Trop. Pediatr. 40:329-333.

220. Sabchareon, A., T. Chongsuphajaisiddhi, and P. Attanath. 1980. Treatment of giardiasis in children with quinacrine, metronidazole, tinidazole and ornidazole. S. Asian J. Trop. Med. Public Health 11:280-284.

221. Sagi, E. F., M. Shapiro, and R. J. Deckelbaum. 1983. Giardia lamblia: prevalence, influence on growth, and symptomatology in healthy nursery children. Isr. J. Med. Sci. 19:815-817.

222. Salih, S. Y., and R. E. Abdalla. 1977. Symptomatic giardiasis in Sudanese adults and its treatment with tinidazole. J. Trop. Med. Hyg. 80:11-13.

223. Samuelson, J. 1999. Why metronidazole is active against both bacteria and parasites. Antimicrob. Agents Chemother. 43:1533-1541.

224. Sealy, D. P., and S. H. Schuman. 1983. Endemic giardiasis and day care. Pediatrics 72:154-158.

225. Smith, P. D., F. D. Gillin, W. M. Spira, and T. E. Nash. 1982. Chronic giardiasis: studies on drug sensitivity, toxin production, and host immune response. Gastroenterology 83:797-803.

226. Smith, P. D., T. C. Quinn, W. Strober, E. N. Janoff, and H. Masur. 1992. Gasirointestinal infections in AIDS. Ann. Intern. Med. 116:63-77.

227. Solomons, N. W. 1982. Giardiasis: nutritional implications. Rev. Infect. Dis. 4:859-869.

228. Sousa, M. C., and J. Poiares-da-Silva. 1999. A new method for assessing metronidazole susceptibility of Giardia lamblia trophozoites. Antimicrob. Agents Chemother. 43:2939-2942.

229. Speelman, P. 1985. Single-dose tinidazole for the treatment of giardiasis. Antimicrob. Agents Chemother. 27:227-229.

230. Steketee, R. W., S. Reid, T. Cheng, J. S. Stoebig, R. G. Harrington, and J. P. Davis. 1989. Recurrent outbreaks of giardiasis in a child care center, Wisconsin. Am. J. Public Health 79:485-490.

231. Sullivan, P. S., H. L. DuPont, R. R. Arafat, S. A. Thornton, B. J. Selwyn, M. A. El Alamy, and A. M. Zaki. 1988. Illness and reservoirs associated with Giardia lamblia infection in rural Egypt: the case against treatment in developing world environments of high endemicity. Am. J. Epidemiol. 127:1272-1281.

232. Suntornpoch, V., and B. Chavalittamrong. 1981. Treatment of giardiasis in children with tinidazole, ornidazole and metronidazole. S. Asian J. Trop. Med. Public Health 12:231-235.

233. Takeuchi, T., S. Kobayashi, M. Tanabe, and T. Fujiwara. 1985. In vitro inhibition of Giardia lamblia and Trichomonas vaginalis growth by bithionol, dichlorophene, and hexachlorophene. Antimicrob. Agents Chemother. 27: 65-70.

234. Taylor, G. D., W. M. Wenman, and D. L. J. Tyrrell. 1987. Combined metronidazole and quinacrine hydrochloride therapy for chronic giardiasis. Can. Med. Assoc. J. 136:1179-1180.

235. Thiriat, L., F. Sidaner, and J. Schwartzbrod. 1998. Determination of $G i$ ardia cyst viability in environmental and faecal samples by immunofluorescence, fluorogenic dye staining and differential interference microscopy. Lett. Appl. Microbiol. 26:237-242.

236. Thompson, R. C. A., J. A. Reynoldson, and A. H. Mendis. 1993. Giardia and giardiasis. Adv. Parasitol. 32:71-160.

237. Thompson, S. C. 1994. Giardia lamblia in children and the child care setting: a review of the literature. J. Paediatr. Child Health 30:202-209.

238. Townson, S. M., G. R. Hanson, J. A. Upcroft, and P. Upcroft. 1994. A purified ferredoxin from Giardia duodenalis. Eur. J. Biochem. 220:439-446.

239. Townson, S. M., J. A. Upcroft, and P. Upcroft. 1996. Characterization and purification of pyruvate:ferredoxin oxidoreductase from Giardia duodenalis. Mol. Biochem. Parasitol. 79:183-193.

240. Tracy, J. W., and L. T. Webster. 1996. Drugs used in the chemotherapy of protozoal infections, p. 987-1008. In J. G. Hardman and L. E. Limbird (ed.), The pharmacological basis of therapeutics, 9th ed. McGraw-Hill Book Co., New York, N.Y.

241. Tripathi, D. M., N. Gupta, V. Lakshmi, K. C. Saxena, and A. K. Agrawal. 1999. Antigiardial and immunostimulatory effect of Piper longum on giardiasis due to Giardia lamblia. Phytother. Res. 13:561-565.

242. Underdown, B. J., I. C. Roberts-Thomson, R. F. Anders, and G. F. Mitchell. 1981. Giardiasis in mice: studies on the characteristics of chronic infection in $\mathrm{C} 3 \mathrm{H} / \mathrm{He}$ mice. J. Immunol. 126:669-672.

243. Upcroft, J., R. Mitchell, N. Chen, and P. Upcroft. 1996. Albendazole resistance in Giardia is correlated with cytoskeletal changes but not with a mutation at amino acid 200 in beta-tubulin. Microb. Drug Resist. 2:303308.

244. Upcroft, J., and P. Upcroft. 1998. My favorite cell: Giardia. Bioessays 20:256-263.

245. Upcroft, J. A., R. W. Campbell, K. Benkali, P. Upcroft, and P. Vanelle. 1999. Efficacy of new 5-nitroimidazoles against metronidazole-susceptible and -resistant Giardia, Trichomonas, and Entamoeba spp. Antimicrob. Agents Chemother. 43:73-76.

246. Upcroft, J. A., R. W. Campbell, and P. Upcroft. 1996. Quinacrine-resistant Giardia duodenalis. Parasitology 112:309-313.

247. Upcroft, J. A., and P. Upcroft. 1993. Drug resistance and Giardia. Parasitol. Today 9:187-190.

248. Upcroft, J. A., and P. Upcroft. 1994. Two distinct varieties of Giardia in a mixed infection from a single human patient. J. Eukaryot. Microbiol. 41: 189-194.

249. Upcroft, J. A., P. Upcroft, and P. F. L. Boreham. 1990. Drug resistance in Giardia intestinalis. Int. J. Parasitol. 20:489-496.

250. Venkatesan, P. 1998. Albendazole. J. Antimicrob. Chemother. 41:145-147.

251. Voogd, C. E. 1981. On the mutagenicity of nitroimidazoles. Mutag. Res. 86:243-277.

252. Ward, W., L. Alvarado, N. D. Rawlings, J. C. Engel, C. Franklin, and J. H. McKerrow. 1997. A primitive enzyme for a primitive cell: the protease required for excystation of Giardia. Cell 89:437-444.

253. Webster, B. H. 1960. Furazolidone in the treatment of giardiasis. Am. J. Dig. Dis. 5:618-622.

254. Wolfe, M. S. 1979. Giardiasis. Pediatr. Clin. North. Am. 26:295-303.

255. Wolfe, M. S. 1975. Giardiasis. JAMA 233:1362-1365.

256. Wolfe, M. S. 1992. Giardiasis. Clin. Microbiol. Rev. 5:93-100.

257. Woo, P. K. 1984. Evidence for animal reservoirs and transmission of Giardia infection between animal species, p. 341-364. In S. L. Erlandsen and E. A. Meyer (ed.), Giardia and giardiasis. Plenum Press, New York, N.Y.

258. World Health Organization Informal Working Group on Echinococcosis. 1996. Guidelines for treatment of cystic and alveolar echinococcosis in humans. Bull. W. H. O. 74:231-242.

259. Yardley, J. H., J. Takano, and T. R. Hendrix. 1964. Epithelial and other mucosal lesions of the jejunum in giardiasis. Jejunal biopsy studies. Bull. Johns Hopkins Hosp. 115:389-406.

260. Youssef, M. Y. M., M. M. Essa, H. A. H. Sadaka, M. M. Eissa, and A. M. Rizk. 1996. Effect of ivermectin on combined intestinal protozoal infection (giardiasis and cryptosporidiosis). J. Egypt. Soc. Parasitol. 26:543-553.

261. Zaat, J. O., T. G. Mank, and W. J. Assendelft. 1997. A systematic review on the treatment of giardiasis. Trop. Med. Int. Health 2:63-82.

262. Zimmerman, S. K., and C. A. Needham. 1995. Comparison of conventional stool concentration and preserved-smear methods with Merifluor Cryptosporidium/Giardia Direct Immunofluorescence Assay and ProSpecT Giardia EZ Microplate Assay for the detection of Giardia lamblia. J. Clin. Microbiol. 33:1942-1943.

263. Ziv, G., and F. G. Sulman. 1974. Distribution of aminoglycoside antibiotics in blood and milk. Res. Vet. Sci. 17:68-74. 